Marquette University

e-Publications@Marquette

6-1-2014

Do CEOs Ever Lose? Fairness Perspective on the Allocation of Residuals Between CEOs and Shareholders

Kalin Kolev

Marquette University, kalin.kolev@marquette.edu

Robert M. Wiseman

Michigan State University

Luis R. Gomez-Mejia

University of Notre Dame

Accepted version. Journal of Management, (June 2014). DOI. (C) 2014 SAGE Publications. Used with permission. 


\title{
Do CEOs Ever Lose?: Fairness Perspective on the Allocation of Residuals Between CEOs and Shareholders
}

\author{
Kalin Kolev \\ Department of Management \\ College of Business Administration \\ Marquette University \\ Milwaukee, WI \\ Robert M. Wiseman \\ Management Department \\ Eli Broad College of Business \\ Michigan State University \\ East Lansing, MI \\ Luis R. Gomez-Mejia \\ Management Department \\ Mendoza College of Business \\ University of Notre Dame \\ Notre Dame, IN
}


NOT THE PUBLISHED VERSION; this is the author's final, peer-reviewed manuscript. The published version may be accessed by following the link in the citation at the bottom of the page.

\section{Abstract}

In this study we introduce a justice perspective to examining the result of bargaining between CEOs and boards over the allocation of firm residuals that ultimately determines CEO compensation. Framing CEO pay as the result of bargaining between CEOs and boards focuses attention on the power of CEOs to increase their share of firm residuals in the form of increased compensation, and the diligence of boards of directors to constrain CEO opportunism. Framing this negotiation through a theory of justice offers an alternative perspective to the search for pay-performance sensitivity. We predict and find that as board diligence in controlling opportunism declines and CEO power increases, CEOs are increasingly able to capture a larger portion of firm residuals relative to shareholders. This finding supports critics who charge that CEO pay violates norms of distributive and procedural justice.

Keywords: CEO compensation, agency theory, board monitoring, distributive justice

Following agency theory prescriptions for controlling agency opportunism (e.g., Eisenhardt, 1989; Jensen \& Meckling, 1976), corporate America increasingly adopted pay schemes that linked a portion of agent compensation to outcomes important to principals. For example, virtually $100 \%$ of CEOs' pay today includes some form of performance contingent pay. This widespread use of contingent pay has provoked a large escalation in the use of equity forms of compensation (particularly restricted stock and stock options) over the past 25 years. The use of equity forms of compensation was thought to tie executive pay more closely to shareholder wealth and led to hundreds of studies attempting to measure this link, generally known as pay-performance sensitivity (Gomez-Mejia \& Wiseman, 1997).

Corresponding to the increased reliance on equity-based pay is a greater increase in the amount of compensation awarded to senior executives, especially CEOs. For example, average CEO compensation rose as much as 614\% in real dollars between 1980 and 2004 compared to a $7 \%$ rise in average worker pay over the same period (Bogle, 2008). Others have also noted extraordinary rise in CEO compensation in recent years, most of it due to increases in equity pay (Bebchuk \& Grinstein, 2005; Frydman \& Saks, 2010; Walsh, 2008). This rise in pay has not gone unnoticed by the media, who question the size of CEO pay packages by noting the growing disparity between

Journal of Management, (June 4, 2014). DOI. This article is (C) SAGE Publications and permission has been granted for this version to appear in e-Publications@Marquette. SAGE Publications does not grant permission for this article to be further copied/distributed or hosted elsewhere without the express permission from SAGE Publications. 
CEO pay and that of other segments of society (Deutsch, 2008; Morgenson, 2013). While agency theory provides a strong foundation for describing the challenges of controlling agent opportunism, its normative views of agent opportunism has left us mired in an endless debate of when or if opportunism is occurring, hindering our ability to control it.

The focus on pay-performance sensitivity as a solution to agent opportunism has brought forth a debate between defenders (Core \& Guay, 2010; Kaplan, 2008) and critics (Bebchuk \& Fried, 2004; Walsh, 2008 ) of senior executive compensation practices. Critics charge that CEO pay is excessive and continues to rise faster than GDP and average worker wages, making it difficult to justify on economic grounds (Bebchuk \& Grinstein, 2005; Frydman \& Saks, 2010), and cite the poor record of research into pay-performance sensitivity (e.g., Tosi, Werner, Katz, \& Gomez-Mejia, 2000). Defenders argue that CEO pay satisfies demands of market efficiency because it coincides with changes in shareholder value (Core \& Guay, 2010; Kaplan, 2008; Nyberg, Fulmer, Gerhart, \& Carpenter, 2010) and reflects increases in the contribution wage needed to compensate for increasing risk and job complexity. Despite more than 1,200 articles published on the subject (Gomez-Mejia, Berrone, \& Franco-Santos, 2010), the lack of agreement on the appropriateness of CEO pay along with the absence of consistent empirical support for its effectiveness in producing shareholder value has led to a stalemate in the debate over executive pay.

Writing from an economics perspective almost 30 years ago, Eccles (1985: 52) drew from anecdotal evidence to conclude that "the problem of fairness-never considered in the literature on agency relationships-was frequently mentioned as an essential aspect of such relationships." An absence of rigorous treatment of this issue still remains true today. This is surprising because, while not made explicit, a concern for fairness underlies much of the controversy surrounding CEO pay as reflected in such comments as "top executives are worth every nickel they get" (Murphy, 1986: 125) and "the research evidence to date strongly supports the conclusion that executives use incentive compensation in ways that benefit themselves at the expense of shareholders" (Devers, Cannella, Reilly, \& Yoder, 2007: 1028). Ironically a large literature on organizational justice has grown

Journal of Management, (June 4, 2014). DOI. This article is (C) SAGE Publications and permission has been granted for this version to appear in e-Publications@Marquette. SAGE Publications does not grant permission for this article to be further copied/distributed or hosted elsewhere without the express permission from SAGE Publications. 
parallel to the agency literature, even though both literatures deal with the allocation of rewards and the extent to which those rewards are deserved. True to its origin and tradition, much of the CEO pay literature continues to be embedded within an agency framework, ignoring the insights of organizational justice scholars.

This study offers a novel interpretation of CEO pay from a deservingness perspective by drawing on both agency and organizational justice models. This combined theoretical lens enhances our understanding of CEO pay by going beyond measuring how closely changes in CEO pay correspond to changes in shareholder wealth to considering the allocation of firm residuals between shareholders and CEOs (i.e., whether the allocation conforms to normative views of distributive justice) and the enabling conditions that may allow this to occur (i.e., whether the allocation of residuals satisfies the normative rules of procedural justice). This is an important issue at a societal level because a sense of deep unfairness may give rise to widespread cynicism about corporate governance if top ranks appear to benefit from gaming the system (Loomis, 2009). Reflecting this view a few years ago, President Obama referred to executive pay, particularly in the financial industry, as "immoral." From a more objective perspective, both justice dimensions have been found to predict a wide array of psychological constructs, such as satisfaction with leaders (Tyler \& Caine, 1981), acceptability of reward allocation decisions (Lissak, 1983), motivation of subordinates (St. Onge, 1993), and commitment to the firm (Mathieu \& Zajac, 1990). Thus, normative views of justice would seem important considerations in determining the allocation of residuals between agents and principals.

In our view, debating the optimality of CEO pay misses a larger and more significant concern over whether CEO pay violates normative views of distributive justice. That is, does agent rent seeking result in distortions to the allocation of firm residuals among firm stakeholders? Empirically, prior research has largely focused on whether the coefficient linking pay to firm performance in models of payperformance sensitivity is positive and significant, largely ignoring the intercept that reflects the proportion of residuals captured by the CEO. Thus, while annual fluctuations in CEO pay may have exhibited a modest association with fluctuations in firm performance, the overall size of CEO pay has risen relative to a variety of economic factors 
(e.g., inflation, GDP, and average wage scales). Recognizing this issue, Kirkland and Burke (2006) quote a Forbes story on CEO pay: "What's at stake, in short, is nothing less than the public trust essential to a thriving free-market economy." Echoing this view, Walsh (2008: 30) notes that "public concern about executive pay is not about the nature of pay/performance sensitivities, nor is it about envy . . . [it] is about fairness." Given the outcry over CEO pay, it is important to determine if CEO pay violates norms of distributive justice. Though Wirtz (2006: 23) laments that "you'll find no such estimates in the literature," we suggest that examining the allocation of firm residuals between CEOs as agents and shareholders as principals provides the estimate Wirtz is seeking.

To address this shortcoming we focus on the question of whether and under what conditions CEOs are able to capture more returns than shareholders, who presumably have primacy rights to firm residuals (Fama \& Jensen, 1983; Hansmann \& Kraakman, 2001; Jensen \& Meckling, 1976). In particular, we suggest that CEOs are able to extract greater returns than shareholders even after controlling for reservation wages paid to CEOs. Furthermore, under certain governance conditions, we find that agents are able to capture even larger returns when measured against shareholder returns signaling that CEO rent seeking is more aggressive when boards are less effective. We offer a fresh new way of conceptualizing and measuring CEO rent seeking which traditionally has been interpreted in terms of agent pay-performance sensitivity. More specifically, we use a residual analysis to ascertain the extent to which CEOs receive returns from equity forms of pay beyond what can be explained by shareholder returns. In essence, we compare the returns realized by CEOs to those realized by shareholders, to determine if CEOs are capturing a larger share of firm residuals relative to shareholders. We suggest that allocations of firm residuals that favor CEOs over shareholders would seem to violate normative views of distributive justice given that classical agency writings and most financial economists posit the latter as holding primary claimant rights to the firm's residuals (e.g., Fama \& Jensen, 1983; Hansmann \& Kraakman, 2001). Comparing CEO returns to shareholder returns has implications for the distribution of firm value among all stakeholders that several have suggested may negatively impact the willingness of others to participate in the firm's value creation efforts (Kirkland \& Burke, 2006; Walsh, 2008; Wirtz, 
2006). In sum, our approach is to break free of theories that fail to provide justification for controlling agent opportunism and introduce a justice perspective that compares CEO compensation relative to a key constituent of the firm, its shareholders.

Full understanding of how CEOs may extract excess returns requires that we also consider the context in which firm residuals are allocated between shareholders and executives. Consistent with our hybrid agency-justice theoretical perspective, we recognize conditions that may exacerbate or constrain the ability of CEOs to capture larger returns at the expense of shareholders. This hybrid perspective breaks free from research that has focused largely on the CEO's payperformance sensitivity. Thus, we recognize that boards of directors, as shareholders' representatives, play an important role in designing and administering executive pay and ensuring against agent opportunism. However, one finds a quagmire similar to that of the pay-performance sensitivity research when it comes to examinations of the effectiveness of boards of directors. While some scholars find evidence that increased board monitoring garners positive stock market reactions, higher bond ratings, and widespread support in the financial community (Bhojraj \& Sengupta, 2003), others find either no effect (see the meta-analysis by Dalton, Daily, Ellstrand, \& Johnson, 1998 ) or worse, a negative board impact on shareholders welfare because through window dressing, impression management, and symbolism decoupled from substantive actions, the appearance of strong board monitoring can promote the self-serving agenda of powerful CEOs (Westphal \& Graebner, 2010; Westphal \& Zajac, 1994, 1998). The resulting confusion that emerges in this literature may be due partly to a failure to fully appreciate the complex nature of boards; while boards have traditionally been looked at through the lens of structural independence, the idea of board diligence has received less attention. Given that CEO pay is the result of a negotiation between the CEO and the board, understanding how agent opportunism is controlled or countenanced requires that we look more closely at board diligence.

Essentially, we find that on average CEO returns exceed the returns of shareholders who purportedly represent the firm's primary residual claimants (cf. Fama \& Jensen, 1983; Hansmann \& Kraakman, 2001; Jensen \& Meckling, 1976), strongly suggesting a lack of

Journal of Management, (June 4, 2014). DOI. This article is (C SAGE Publications and permission has been granted for this version to appear in e-Publications@Marquette. SAGE Publications does not grant permission for this article to be further copied/distributed or hosted elsewhere without the express permission from SAGE Publications. 
distributive justice in the allocation of residuals. While there might be disagreement as to the optimal or even reasonable allocation of firm residuals between principals and agents, one suspects that CEO returns that consistently supersede shareholder returns over the business cycle, even after controlling for the CEO's reservation wages, represent an agency cost, especially if CEOs simultaneously can insulate themselves from risk.

This article contributes to existing research in several ways. First, we link agency theory to organizational justice theory, creating a powerful interdisciplinary model that can be used to study pay deservingness at the top executive rank, a construct that is central to the legitimacy of any incentive system. Second, we argue and find support that CEO returns in excess of shareholder returns are partly explained ironically by the use of performance-contingent pay intended to align CEO interests with those of shareholders. That is, agency prescriptions suggested for controlling CEO opportunism by tying a portion of CEO pay to the performance of the firm's stock (and thus shareholder wealth) may be partly responsible for the breakdown in alignment between CEO pay and firm performance resulting in a violation of normative views of distributive justice. This contrasts with the normative views underlying pay-performance sensitivity research that views CEO pay as acceptable if it corresponds to fluctuations in firm performance. Third, we outline the factors that facilitate or constrain CEOs from capturing excess returns and that undermine the control of agent rent seeking. In other words, we theorize on the factors that tilt the balance of power between CEOs and shareholders when contingent forms of pay such as stock options are supposed to control agent opportunism. Thus, we enhance traditional approaches to board monitoring by focusing on often overlooked dimensions that are critical for constraining agent opportunism, and which raise issues of procedural justice in how firm residuals are allocated through the negotiation of CEO pay. Finally, we take a different approach to studying the control of agent opportunism by proposing an innovative method of examining the relative distribution of firm residuals between CEOs and shareholders.

Journal of Management, (June 4, 2014). DOI. This article is (C) SAGE Publications and permission has been granted for this version to appear in e-Publications@Marquette. SAGE Publications does not grant permission for this article to be further copied/distributed or hosted elsewhere without the express permission from SAGE Publications. 
NOT THE PUBLISHED VERSION; this is the author's final, peer-reviewed manuscript. The published version may be accessed by following the link in the citation at the bottom of the page.

\section{Theory and Hypotheses}

Among publically traded firms where ownership is separated from control, CEOs are hired to formulate and implement strategies that will generate profits and earn positive rents for shareholders. To overcome CEO shirking and motivate CEOs to be diligent guardians of shareholder wealth, principals purportedly design compensation contracts where a sizeable part of CEO pay is linked to firm performance. In theory this is intended to create alignment in the interests of CEOs and shareholders over the creation of shareholder value. Embedded in prescriptions for creating incentive alignment is the shared belief that maximizing shareholder value by limiting agent rent seeking is the principal goal of corporate governance (Jensen \& Meckling, 1976). In practice, empirical evidence of this alignment is scant (Bebchuk \& Fried, 2004; Tosi et al., 2000). Empirical examinations of pay-performance sensitivity find at best weak and often inconsistent associations between CEO pay and firm performance. Thus, while increased use of equity-based pay would seem to ensure a link between CEO incentives and shareholder value creation, such a link has yet to materialize in any consistent way. Meanwhile, CEO pay has risen, resulting in an ever larger share of firm residuals.

Reliance on so-called incentive alignment mechanisms for controlling agent opportunism has resulted in an exponential rise in total CEO compensation driven by use of equity forms of compensation. This increase in CEO pay comes in stark contrast to lesser growth exhibited by the economy, the average wages of employees and inflation in general (e.g., Bebchuk \& Grinstein, 2005; Bogle, 2008; Deutsch, 2008; Frydman \& Saks, 2010; Morgenson, 2013; Walsh, 2008). That is, during the pursuit of a stronger association between pay and performance, CEOs have somehow captured an increasing share of firm residuals that is difficult to justify as optimal given that CEO pay remains largely insensitive to fluctuations in firm performance (Bebchuk \& Fried, 2004). The growing disparity between the increases in CEO pay and that of other segments of the economy raises issues about the roots of social inequality, in particular whether CEOs are receiving more than their fair share of firm residuals and what has allowed this to occur. Indeed, it would be

Journal of Management, (June 4, 2014). DOI. This article is (C) SAGE Publications and permission has been granted for this version to appear in e-Publications@Marquette. SAGE Publications does not grant permission for this article to be further copied/distributed or hosted elsewhere without the express permission from SAGE Publications. 
difficult to justify on normative grounds having agents who are already highly paid to have greater access to residuals than investors who risk their capital in the firm and whom most agency scholars would agree represent the primary claimants to returns on their investment. All of these concerns are reflective of socially constructed norms regarding distributive justice between investors and executives of public companies.

To understand how CEO pay has risen, we must consider the process by which CEO pay is determined. To do this we view CEO pay as the outcome of a bargaining process between the CEO and the board of directors. Thus, outcomes of this process are likely influenced by the ability and power of the CEO vis-à-vis representatives of the shareholders (i.e., board of directors) to extract value from the firm in the form of additional compensation. In other words, CEO compensation and rewards are the outcome of a bargaining process between the CEO and the board where the former would prefer more pay over less and less risk over more risk, while the latter would prefer to pay less and transfer some risk onto the agent. Typically the compromise between these opposing preferences has led to greater reliance on equity forms of pay and correspondingly an escalation in the overall amount paid to CEOs (e.g., Bebchuk, \& Grinstein, 2005). Alternatively, if the CEO is not able to or does not know how to secure extra value for herself or himself, it is less likely that principals and the board of directors in particular will voluntarily award larger payments, which directly affect their own firm wealth (e.g., Williamson, 1985).

This leads us to ask when and under what conditions either the CEO is able to extract greater amounts of wealth or the principals can constrain CEO rent seeking and limit the portion of firm residuals captured by the CEO. Viewing the relationship between CEOs and the board of directors (representing shareholders) as a battle over firm's residuals (Williamson, 1985), we argue that two broad categories of factors-CEO structural power and governance structures-would make the CEO or the board more powerful and able to extract larger or smaller shares of firm residuals.

Viewing CEO pay as the result of a bargaining process between parties who vary in their ability and power to influence the outcome focuses attention on the nature of this process and whether failures in procedural justice may help explain departures from distributive

Journal of Management, (June 4, 2014). DOI. This article is (C) SAGE Publications and permission has been granted for this version to appear in e-Publications@Marquette. SAGE Publications does not grant permission for this article to be further copied/distributed or hosted elsewhere without the express permission from SAGE Publications. 
justice. Specifically, procedural justice is a necessary precondition for distributive justice (Greenberg, 1990); hence examining factors that influence the process of allocating firm residuals among stakeholders, especially allocations to the CEO in the form of compensation, may help us better understand how violations of distributive justice might occur. Thus, we begin by examining for evidence of distributive justice failure by comparing CEO returns to those of shareholders, while also considering how factors influencing this process may violate issues of procedural justice.

\section{Distributive Justice Failure}

Distributive justice reflects the allocation of resources among members of a society and whether that allocation corresponds to socially shared beliefs about how those resources should be allocated. Different societies may hold different beliefs about what constitutes distributive justice. For example, some societies may accept a creed in which resources are allocated to people based on need, and from people based on ability (Marx, 1906), while others may favor a model of distribution based solely on merit (Smith, 1937). Within a capitalist system, owners of valuable assets (such as investors in a corporation) are traditionally given primary claimant rights to the residual value produced by those assets (Hansmann \& Kraakman, 2001). Specifically, societies that view distributive justice through the lens of capitalism acknowledge that in exchange for their willingness to accept the risk that their investment may or may not provide a positive return, owners are granted primary claimant rights to firm residuals. This should be reflected in the returns they realize from their investment. This arrangement has positive benefits for society by encouraging investment in entrepreneurial ventures and thus the creation of new value that is ultimately distributed among all stakeholders.

The tremendous success of this system has led to the separation of ownership from control due to a need to pool resources from multiple investors to continue developing and expanding valueproducing assets. Thus, dispersed owners hire agents to manage their investment making owners vulnerable to agent opportunism (Berle \& Means, 1932). Though various mechanisms are employed to control agent opportunism, both empirical research and conventional wisdom

Journal of Management, (June 4, 2014). DOI. This article is (C) SAGE Publications and permission has been granted for this version to appear in e-Publications@Marquette. SAGE Publications does not grant permission for this article to be further copied/distributed or hosted elsewhere without the express permission from SAGE Publications. 
suggest that agents may be winning the battle with shareholders over the allocation of firm value. If true, this suggests a breakdown in the normative views of distributive justice regarding the socially accepted norm for allocating firm residual value between owners and agents. Specifically, if agents are capturing a larger portion of firm value than shareholders, even after compensating CEOs for their human capital investment (i.e., their reservation wages), this would appear prima facie evidence that traditional notions of resource allocation between agents and principals are being violated. Said formally,

Hypothesis 1: The use of equity-based pay in CEO compensation results in CEOs realizing higher returns from equity than shareholders thus violating norms of distributive justice in the allocation of firm residuals between agents and principals.

\section{Procedural Justice Failure}

Procedural justice concerns the fairness in allocation processes (Leventhal, 1980; Leventhal, Karuza, \& Fry, 1980; Thibaut \& Walker, 1975). This literature identifies six rules that are associated with the perceived fairness of allocation processes: consistency, bias suppression (including both the transparency and impartiality of the process), objectivity, diligence in addressing issues and taking corrective action if necessary, representation of the affected parties, and compliance with culturally accepted norms of fairness. These rules have been empirically demonstrated to influence perceptions of the fairness of allocation decisions and ultimately individual behavior, including the behavior of those not directly affected by the allocation process (Colquitt, Conlon, Wesson, Porter, \& Ng, 2001). In the context of principal-agent relations, we contend that justice is served if the procedure for allocating firm residuals is consistent across agents and time, if no individual party is favored over others, if the allocation is based on accurate information and informed opinion, if there is due diligence among those responsible to make the allocation, if all stakeholders affected by the allocation are represented, and if cultural norms of fairness and equity are followed.

A large literature indicates that when managers are in control of the firm they tend to pursue compensation policies that benefit them at the expense of atomistic owners (Bebchuk \& Fried, 2004; see also

Journal of Management, (June 4, 2014). DOI. This article is (C) SAGE Publications and permission has been granted for this version to appear in e-Publications@Marquette. SAGE Publications does not grant permission for this article to be further copied/distributed or hosted elsewhere without the express permission from SAGE Publications. 
Tosi et al., 1999, for review), and it is possible for powerful CEOs to take advantage of other principals due to their central position in allocating firm wealth among the various stakeholders. The potential for CEOs to leverage their position to capture a larger share of residuals would seem to violate the rule of bias suppression in procedural justice. As noted earlier, if CEO returns are in excess of shareholder returns, this would seem to be evidence of bias favoring the CEO in the allocation of firm residuals. Given that CEOs are already well paid for their human capital through a variety of perquisite and nonperquisite rewards, this bias would be difficult to justify from a normative perspective.

An important discretionary factor likely to facilitate or hinder CEO's accrual of excess returns is this individual's structural power within the firm. Research by Hambrick and Cannella (2004) and Finkelstein and Hambrick (1989), among others, suggests that as the structural position of the CEO within the firm increases his or her influence over organizational decisions strengthens accordingly. While it is true that even powerful CEOs operate within the constraints of preexisting governance structures, they may enjoy disproportionate influence to tilt the balance in their favor when it comes to a sharing of firm residuals. Consistent with a social stratification view (Pfeffer, 1981), we hypothesize that an important predictor of CEO relative returns is the power that resides in the top executive suite.

Research on employee compensation and negotiation is clear that agents have their strongest bargaining power in negotiating their employment agreement at the time of their initial appointment when they enjoy greater freedom to walk away. For example, evidence suggests that outside CEO hires earn approximately $13 \%$ to $15.3 \%$ more than internal hires (Harris \& Helfat, 1997; Murphy \& Zabojnik, 2004). Those being hired into the CEO position are most likely to take advantage of this situation for several reasons. First, new CEOs can take advantage of small numbers bargaining in which negotiation is restricted to a single partner. This is because boards generally negotiate with candidates sequentially, such that they negotiate with their preferred candidate and only when they cannot reach a mutually agreeable contract will they open negotiations with a second candidate. This approach clearly puts the candidate in a stronger position when negotiating compensation, and this stance would be

Journal of Management, (June 4, 2014). DOI. This article is @ SAGE Publications and permission has been granted for this version to appear in e-Publications@Marquette. SAGE Publications does not grant permission for this article to be further copied/distributed or hosted elsewhere without the express permission from SAGE Publications. 
exaggerated further if she or he is currently employed elsewhere. Second, boards are likely to hold optimistic views about the potential contributions of a new CEO based on the candidate's prior success. This optimism may inflate the value they initially attribute to the CEO's human capital, thus justifying concessions to the CEO's demands. Finally, both parties are generally represented by outside council or by consulting firms specializing in executive compensation. These representatives have access to compensation data from other firms that are used in supporting their demands. If boards have a strong interest in hiring the candidate, they are likely to concede to demands supported by data provided by the candidate's representative.

In sum, the negotiation of CEO compensation and thus the allocation of firm residuals between the CEO and shareholders appear to violate several features of procedural justice and may offer some explanation for violations of distributive justice in which shareholders take a backseat to CEOs. In the next section we suggest that bargaining between CEOs and the board of directors over the allocation of firm residuals is likely to change over time due to changes in the CEO's structural power and the nature of governance structure employed to control agent opportunism.

\section{CEO Structural Power}

A long string of research has brought onto center stage the internal struggle among corporate actors who often scramble to pursue pluralistic goals even if this comes at the expense of other stakeholders (Berle \& Means, 1932; Jensen \& Meckling, 1976; Westphal \& Graebner, 2010). The bargaining between an executive as agent and those representing the principal over allocation of firm residuals represents one such struggle (Coffee, 1988; Williamson, 1985). Drawing on prior research, we outline two indicators of CEO structural power-CEO tenure and CEO duality.

\section{The dual nature of tenure in CEO structural power}

Prior research on CEO tenure offers inconclusive findings whether tenure garners higher or lower power to CEOs. In particular, while the literature on human capital and CEO obsolescence argues that longer tenure is associated with lower CEO power, the literature

Journal of Management, (June 4, 2014). DOI. This article is @ SAGE Publications and permission has been granted for this version to appear in e-Publications@Marquette. SAGE Publications does not grant permission for this article to be further copied/distributed or hosted elsewhere without the express permission from SAGE Publications. 
on CEO entrenchment posits that longer-tenure CEOs enjoy greater power inside the firm. We suggest the reason for the lack in consistent findings is that two opposing factors affect the CEO's power as CEO tenure increases: the decaying of the CEO's human capital and their growing entrenchment in the position of CEO. The former corresponds to a weakening of power, while the latter enhances CEO power.

As noted above, CEOs are likely to have very high relative bargaining power when initially hired. Barring continued success, the power of the CEO to act unilaterally may decline over time due to obsolescence. The CEO's human capital may not fit with the firm or become stale and its quality deteriorate with a changing environment, leading to the choice of strategies that lack fit with the environment (Miller, 1991) and harm performance (Henderson, Miller, \& Hambrick, 2006). In addition, the longer CEOs remain with a firm the more firmspecific capital they will develop, which may have limited value to other firms. That is, long-tenured CEOs not only offer a smaller contribution to the firm's success, but also have fewer employment alternatives given that their human capital increasingly lacks market value. From a bargaining perspective (e.g., Kim \& Fragale, 2005; Pinkley, Neale, \& Bennett, 1994), the smaller the CEO's contribution and the fewer alternative employment opportunities available due to their diminishing human capital, the lower the CEO's power vis-à-vis the board. As a result, as tenure increases, CEO power declines due to increased obsolescence leading to lower CEO relative returns from the firm.

The literature on CEO entrenchment argues for an opposite impact of CEO tenure. The longer CEOs stay in office, the more power they are able to garner (e.g., Hambrick \& Fukutomi, 1991; Hill \& Phan, 1991). In particular, CEOs may increase their influence in the firm over time through a variety of tactics including ingratiating themselves with key constituents, manipulating and selecting board members, or establishing a strong record of performance (e.g., Mace, 1971; Westphal, 1998; Westphal \& Zajac, 1995). These contributors to CEO power, often summarized as factors underlying CEO entrenchment, have been associated with increased opportunism (e.g., Combs \& Skill, 2003; Ocasio, 1994). Thus, over time CEOs could increase their power vis-à-vis the board and be able to request and receive larger shares of firm residuals.

Journal of Management, (June 4, 2014). DOI. This article is (C) SAGE Publications and permission has been granted for this version to appear in e-Publications@Marquette. SAGE Publications does not grant permission for this article to be further copied/distributed or hosted elsewhere without the express permission from SAGE Publications. 
We believe that these opposing perspectives combine to influence the power of CEOs over time. However, we posit that CEO obsolescence is more likely to affect CEO power early in the CEO's tenure, while entrenchment is likely to counterbalance that effect later in the CEO's tenure, resulting in a nonlinear association between power and CEO relative returns. This occurs because entrenchment effects require time to develop, while human capital may begin to decay early with changes in environmental conditions, performance consequences that fail to satisfy early expectations, or simply limits to the CEO's ability to contribute. Thus, we would expect tenure will exhibit a negative association with CEO relative returns, but this association will shift toward a positive association in later years as the CEO's deepening entrenchment reverses her or his declining power. Thus, we propose a convex relationship between CEO tenure and CEO relative returns where the latter will decrease at a diminishing rate with increases in CEO tenure:

Hypothesis 2: CEO tenure exhibits a U-shaped association with CEO relative returns such that CEO returns relative to shareholder returns decrease initially over time, but later rise due to increasing entrenchment.

\section{CEO duality as a violation of procedural justice}

Another indicator of CEO structural power and thus a threat to bias suppression in the allocation process is when a CEO also occupies the position of board chairman. In general, duality renders more power to the CEOs and weakens the ability of the board to challenge and oversee the CEO (e.g., Cannella \& Lubatkin, 1993). A CEO who also presides over the board of directors has enormous power over directors and could influence the agenda, deliberations, and decisions in the boardroom (Finkelstein \& D'Aveni, 1994). As a result, not only can a CEO chair filter information to the board, but also she or he could represent excess CEO returns as appropriate and justified. Prior research also suggests that "CEOs who serve as board chairs gain influence over board member nominations, compensation setting, board agendas, and so forth, even if they do not formally serve on the committees charged with those responsibilities" (O'Connor, Priem, Coombs, \& Gilley, 2006: 487), which ultimately undermines board monitoring (Finkelstein \& D'Aveni, 1994; Tuggle, Sirmon, Reutzel, \& Bierman, 2010) and reduces the ability and motivation of directors to

Journal of Management, (June 4, 2014). DOI. This article is (C) SAGE Publications and permission has been granted for this version to appear in e-Publications@Marquette. SAGE Publications does not grant permission for this article to be further copied/distributed or hosted elsewhere without the express permission from SAGE Publications. 
NOT THE PUBLISHED VERSION; this is the author's final, peer-reviewed manuscript. The published version may be accessed by following the link in the citation at the bottom of the page.

constrain the CEO rent seeking. Overall, the existence of duality should allow CEOs to more easily capture a larger portion of firm residuals, and violates a rule of procedural justice, notably the requirement of impartiality as reflected in suppression. Thus,

Hypothesis 3: CEO duality exhibits a positive association with CEO relative returns compared to shareholder returns.

\section{Governance Structures}

Boards of directors play a key role in determining CEO compensation, given their formal authority to negotiate with CEOs over distribution of the firm's joint outputs (e.g., Williamson, 1985). That is, boards negotiate with CEOs over pay amount and pay design, such as the amount of pay linked to achievement of firm outcomes important to shareholders. Linking pay to firm performance is thought to increase incentive alignment between agents and principals (see Murphy, 1999, for a survey of CEO compensation and agency contracting) and is argued to be a desirable mechanism for protection of shareholder interests (Jensen \& Meckling, 1976). Assuming that agent selfinterests are likely to diverge from those of shareholders (Jensen \& Meckling, 1976), it then follows that the preferences of the two negotiating parties diverge. The resulting balance among these competing interests is likely to be a function of the effort each side puts into negotiating on their own behalf. Though CEOs clearly are motivated to bargain for more pay and less risk since they benefit directly from winning in these negotiations, it is less clear how much incentive boards have in tempering CEO desires.

\section{Board Diligence}

Agency theorists have long argued that the board should be independent if it is to diligently perform its monitoring and reward functions (Fama \& Jensen, 1983). From a procedural perspective this should result in an allocation of residuals that reflects normative views of distributive justice. Furthermore, there is a strong tradition emanating from the human resource management literature that there should be some emotional distance and lack of vested interests between those who judge and those being judged (Eccles, 1985). This view rests on arguments that the appraisal of individual merit and

Journal of Management, (June 4, 2014). DOI. This article is (C) SAGE Publications and permission has been granted for this version to appear in e-Publications@Marquette. SAGE Publications does not grant permission for this article to be further copied/distributed or hosted elsewhere without the express permission from SAGE Publications. 
judgment of pay deservingness demand some reasonable degree of objectivity in the assessment process even though validity and reliability of evaluation results will never be perfect (e.g., Milkovich, Newman, \& Gerhart, 2013).

Building on this view there has been considerable though largely unsuccessful effort at empirically linking board independence as reflected in the proportion of outside directors to the control of agency costs (e.g., Dalton, Daily, Johnson, \& Ellstrand, 1999; Dalton et al., 1998). A primary reason for the failure of board independence to demonstrate a strong role in controlling agency costs is suggested by the sociopolitical perspective of corporate governance, which highlights how top executives seek to manage the impressions of external constituents about governance structures, policies, and procedures (Westphal \& Zajac, 1994, 1998; Zajac \& Westphal, 1995). According to this view, self-serving CEOs can enhance the legitimacy of high compensation packages with limited risk by demonstrating conformity to the prevailing ideologies or institutional forces by symbolically appointing more outside directors to the full board who share strong social ties with them. External constituents, the media, and governance scholars, observing formally independent boards with a high level of structural legitimacy, may erroneously assume that such a board will also have higher process legitimacy to effectively control managerial self-interest (Suchman, 1995). In the words of Westphal and Graebner (2010: 16) "powerful leaders can give the impression of enhancing the board's control capacity, without actually increasing its propensity to exercise control, by making changes in board composition that increase the board's formal independence from management without increasing (or even decreasing) its social independence." Thus, board independence has generally failed to reflect the underlying motivations of board members in controlling CEO opportunism. In other words, from a procedural justice perspective stacking a board of directors with members who exhibit economic independence but who share strong social ties to the CEO raises questions about the ability of the board to adequately represent the interests of shareholders.

To capture the board's incentive to control agency costs when bargaining over firm residuals with the CEO, we propose to examine board diligence defined as the degree of director motivation and ability

Journal of Management, (June 4, 2014). DOI. This article is (C) SAGE Publications and permission has been granted for this version to appear in e-Publications@Marquette. SAGE Publications does not grant permission for this article to be further copied/distributed or hosted elsewhere without the express permission from SAGE Publications. 
in fulfilling board responsibilities. Focusing on board diligence avoids equating structural characteristics of the board, such as economic independence, with the board's motivation as has been done in some prior research where the concept of vigilance has been subsumed within board independence (e.g., Kroll, Walters, \& Wright, 2008). Thus, we suggest that from a procedural perspective board diligence represents a crucial factor in assessing the degree to which boards make a fair allocation of firm residuals and thus avoid situations where CEO returns exceed those of shareholders. Assuming boards are charged with representing the interests of shareholders when negotiating the CEO's pay package, linking board diligence to CEO relative returns should indicate the degree to which interests of shareholders are adequately represented in this allocation decision.

From an agency theoretic perspective board diligence is associated with the motivation of board members to control agency costs and their motivation is likely strong with the amount of equity they own in the firm. As a result, they are less likely to bequeath a larger share of residuals to the CEO since these residuals would come at their expense due to the fact of directors being partial owners in the firm. That is, board equity makes the board a residual claimant and thus engenders greater motivation on the part of directors as principals to prevent CEOs from obtaining a larger share than they receive (Dalton, Daily, Certo, \& Roengpitya, 2003). Alternatively, director equity ownership encourages the board to be more diligent in its fiduciary duties and to stay more cautious toward the CEO's outwardly aggressive or obvious rent-seeking behavior. In other words, when the board is properly motivated to represent shareholder interests, we would expect that CEO opportunism in the form of CEO relative returns is more likely constrained.

In addition, board diligence is also related to the ability of directors to constrain CEO opportunism. Such ability likely depends on the level of director attendance at board meetings. Regular attendance at board meetings should provide directors with detailed information on the CEO's intentions and efforts as well as offering them more thorough knowledge for accurately evaluating the CEO, conducting proper monitoring, and fulfilling their fiduciary duties to the firm. If directors miss many board meetings, the CEO is more likely to take

Journal of Management, (June 4, 2014). DOI. This article is (C) SAGE Publications and permission has been granted for this version to appear in e-Publications@Marquette. SAGE Publications does not grant permission for this article to be further copied/distributed or hosted elsewhere without the express permission from SAGE Publications. 
NOT THE PUBLISHED VERSION; this is the author's final, peer-reviewed manuscript. The published version may be accessed by following the link in the citation at the bottom of the page.

advantage of their absence to extract larger returns. This logic leads to our fourth hypothesis:

Hypothesis 4: Board member diligence exhibits a negative association with CEO relative returns compared to shareholder returns.

\section{Method}

\section{Sample and Data}

Data for this study were drawn from several sources: financial data from Compustat, executive compensation data from Execucomp, and board-level data from Bloomberg, Risk Metrics, and Corporate Library's Historical Data. Our data were collected for the years 2001 through 2008. This resulted in a final sample size of 2,864 individual CEO-year observations for testing our hypothesized relationships.

\section{Dependent Variable}

\section{CEO relative returns}

We define CEO relative returns as returns on CEO equity-based compensation relative to shareholder returns. CEO returns in excess of shareholder returns after controlling for other forms of CEO pay would seem to represent a failure of normative views of distributive justice in which shareholders presumably are the primary claimants of firm residuals (Hansmann \& Kraakman, 2001). Analogous to the shareholder wealth maximization goal of incentive alignment, we compare CEO returns to shareholder returns as proxy for assessing the allocation of firm residuals between agents and principals. To create our measure of CEO relative returns, we first measured the annual change in CEO wealth resulting from contingent pay (producing CEO returns) and regressed this measure on annual shareholder returns controlling for CEO turnover, firm size, firm performance, and firm risk. A full description of how this measure was calculated can be found in the appendix. The latter variables control for human capital and personal risk factors that are not shared by shareholders (see Table 1 for descriptive statistics). This regression model is used to test Hypothesis 1 . In essence, this approach allows us to directly compare the annual returns accrued by CEOs on their equity holdings (including

Journal of Management, (June 4, 2014). DOI. This article is @ SAGE Publications and permission has been granted for this version to appear in e-Publications@Marquette. SAGE Publications does not grant permission for this article to be further copied/distributed or hosted elsewhere without the express permission from SAGE Publications. 
NOT THE PUBLISHED VERSION; this is the author's final, peer-reviewed manuscript. The published version may be accessed by following the link in the citation at the bottom of the page.

changes in the intrinsic value of stock options) to the returns that shareholders receive on their equity holdings (including dividends). In general, a regression coefficient on shareholder returns larger than 1 would indicate that CEOs are capturing a larger share of firm residuals than shareholders. Results from this procedure are presented in Table 2.

Table 1

\section{Descriptive Statistics and Correlation Coefficients for Modeling CEO Returns}

\begin{tabular}{lcccccccc}
\hline Variable & $M$ & $S D$ & 1 & 2 & 3 & 4 & 5 & 6 \\
\hline 1. CEO returns $_{\mathrm{t}}$ & 0.26 & 0.96 & 1 & & & & & \\
2. Shareholder returns $_{\mathrm{t}}$ & 0.09 & 0.45 & .57 & 1.00 & & & & \\
3. Prior performance $_{\mathrm{t}-1}$ & 0.03 & 0.13 & -.14 & -.06 & 1.00 & & & \\
4. Firm size $_{\mathrm{t}-\mathrm{1}}$ & 7.24 & 1.65 & .004 & -.02 & .26 & 1.00 & & \\
5. Performance volatility $_{\mathrm{t}-1}$ & 0.48 & 0.24 & .08 & .06 & -.4 & -.42 & 1.00 & \\
6. CEO change $_{\mathrm{t}-1}$ & 0.13 & 0.33 & .12 & -.01 & -.07 & .02 & .06 & 1.00 \\
\hline
\end{tabular}

Note: $N=10,156$. Correlation coefficients larger in absolute value than .02 are significant at $p<.05$.

Table 2

Arellano-Bond Dynamic Panel Regression of CEO Returns

\begin{tabular}{|c|c|c|}
\hline \multirow[b]{2}{*}{ Variable } & \multicolumn{2}{|c|}{ Model 1} \\
\hline & Coeff. & $S E$ \\
\hline Constant & -0.03 & 0.06 \\
\hline Lagged CEO returns & 0.0001 & 0.09 \\
\hline Shareholder returns & $1.295^{* * *}$ & 0.03 \\
\hline Firm performance $_{t-1}$ & $-0.68 * * *$ & 0.12 \\
\hline Firm size $_{t-1}$ & $0.02 * * *$ & 0.01 \\
\hline Performance volatility ${ }_{t-1}$ & 0.02 & 0.06 \\
\hline CEO change & $0.33^{* * *}$ & 0.04 \\
\hline Year dummies & \multicolumn{2}{|c|}{ Included } \\
\hline$N$ & \multicolumn{2}{|c|}{10,034} \\
\hline $\begin{array}{l}\text { Wald } \chi^{2} \\
p \text { values }\end{array}$ & \multicolumn{2}{|c|}{$3289 * * *$} \\
\hline $\mathrm{AR}(1)$ test & \multicolumn{2}{|c|}{.00} \\
\hline $\mathrm{AR}(2)$ test & \multicolumn{2}{|c|}{.13} \\
\hline Hansen test & \multicolumn{2}{|c|}{.21} \\
\hline
\end{tabular}

Note: $S E=$ robust standard errors. The last three rows provide specification tests for the Arellano-Bond generalized method of moments (GMM) system estimator. The $z$ statistic for the AR(2) test equals 1.5 and the $p$ value exceeds .1 , which indicate no serial autocorrelation. The Hansen statistic $(12$ and $p>.21)$ indicates that instruments are exogenous and valid since the $p$ value exceeds .1 (Lim \& McCann, 2013; Vandaie \& Zaheer, 2014).

$* * * p<.001$.

Journal of Management, (June 4, 2014). DOI. This article is @ SAGE Publications and permission has been granted for this version to appear in e-Publications@Marquette. SAGE Publications does not grant permission for this article to be further copied/distributed or hosted elsewhere without the express permission from SAGE Publications. 
We use the residuals from the model above as our DV in testing Hypotheses 2 to $4 .{ }^{1}$ Essentially, our DV (CEO relative returns) represents the amount of unexplained movement in CEO returns relative to shareholder returns and firm performance. Similar approach has been utilized in prior research focusing on whether CEOs receive appropriate pay and whether their pay reflects objective economic and organizational conditions (e.g., Fong, Misangyi, \& Tosi, 2010; Wade, O'Reilly, \& Pollock, 2006). Our approach is methodologically preferable to creating a difference variable that subtracts shareholder returns from CEO returns. Difference variables have been criticized for producing problems of interpretation as well as potentially biasing associations (Edwards, 1996; Wiseman, 2009). Furthermore, we avoid using a ratio of CEO returns to shareholder returns (cf. Nyberg et al., 2010) because our purpose is to examine whether and why CEOs extract a greater share of residuals than shareholders; a regression approach allows us to appropriately capture the core construct of CEO relative returns.

\section{Independent Variables}

CEO tenure (Hypothesis 2) reflects the relative structural power of the CEO in the company. CEO tenure is measured as the number of years the CEO has been in office (e.g., Henderson et al., 2006).

CEO duality (Hypothesis 3 ) is measured as 1 if the CEO and board chairman positions are held by the same person and 0 otherwise (Boyd, 1995). ${ }^{2}$

Board diligence (Hypothesis 4) is represented by board incentives and board attendance. Board incentives is calculated as the proportion of equity-based pay to total director pay received by board members (Tian, Haleblian, \& Rajagopalan, 2011). Board attendance is calculated first as the number of directors who have missed at least $75 \%$ of annual meetings (Risk Metrics, 2013). This variable is then reverse coded so that, like with board incentives, higher values correspond to higher levels of diligence.

Journal of Management, (June 4, 2014). DOI. This article is (C) SAGE Publications and permission has been granted for this version to appear in e-Publications@Marquette. SAGE Publications does not grant permission for this article to be further copied/distributed or hosted elsewhere without the express permission from SAGE Publications. 
NOT THE PUBLISHED VERSION; this is the author's final, peer-reviewed manuscript. The published version may be accessed by following the link in the citation at the bottom of the page.

\section{Control Variables}

We control for several factors that provide additional indicators of governance control over agency costs including institutional ownership, board independence, board size, and board meetings. Institutional ownership is modeled as a dummy variable that is coded 1 if there exists at least one owner with a large ownership position, and 0 if not. Prior research argues that institutional investors are "a store of potential influence" (Pfeffer, 1981: 52) and serve to align the interests of agents and principals (Dalton et al., 2003). Board independence is the percentage of board members who are classified as neither "inside" nor "related outside," where related outside is defined as board members with economic ties to the firm (e.g., bankers, suppliers) outside of their position on the board of directors (Dalton et al., 1998). The correlation between board incentives and full board independence is -.002 , and the correlation between board attendance and full board independence is .01, indicating that these dimensions are distinct from one another (see correlation matrix, Table 3). Board size represents the total number of members serving on the firm's corporate board (Core, Holthausen, \& Larcker, 1999). Board meetings is the total number of meetings held annually. The more meetings held by the board, the more information board members are likely to consider and more involved they appear to be in the firm's affairs. However, board meetings may also reflect serious problems facing the firm requiring frequent meetings. Hence, while it is an important control, its interpretation is less clear.

\begin{tabular}{|c|c|c|c|c|c|c|c|c|c|c|c|c|c|c|c|c|}
\hline & & Desc & riptiv & Stati & ics an & Corr & $\begin{array}{l}\text { ble } 3 \\
\text { lation }\end{array}$ & Coef & cients & or Fu & $\mathrm{I} \mathrm{Moc}$ & & & & & \\
\hline Variable & $M$ & $S D$ & 1 & 2 & 3 & 4 & 5 & 6 & 7 & 8 & 9 & 10 & 11 & 12 & 13 & 14 \\
\hline 1. CEO relative returns & 0.006 & 0.67 & 1.00 & & & & & & & & & & & & & \\
\hline 2. Board size & 9.6 & 2.5 & .01 & 1.00 & & & & & & & & & & & & \\
\hline 3. CEO variable pay & 0.48 & 0.27 & -.00 & .05 & 1.00 & & & & & & & & & & & \\
\hline 4. Peer pay & 4952 & 2349 & .02 & .11 & -.01 & 1.00 & & & & & & & & & & \\
\hline 5. Board meetings & 7.4 & 2.9 & .03 & .10 & .04 & .01 & 1.00 & & & & & & & & & \\
\hline 6. Institutional ownership & 0.85 & 0.36 & -.05 & -.01 & .09 & .02 & -.04 & 1.00 & & & & & & & & \\
\hline 7. $\mathrm{CEO}$ age & 55.7 & 6.9 & -.12 & .08 & -.13 & .01 & -.04 & -.02 & 1.00 & & & & & & & \\
\hline 8. Pay gap & 0.82 & 0.78 & .02 & .03 & .03 & .08 & -.00 & .06 & .08 & 1.00 & & & & & & \\
\hline 9. Board independence & 0.7 & 0.15 & .05 & .11 & .13 & -.05 & .07 & .05 & .02 & .19 & 1.00 & & & & & \\
\hline 10. CEO tenure & 7.8 & 7.4 & -.13 & -.12 & -.12 & .04 & -.16 & -.04 & .45 & .04 & -.14 & 1.00 & & & & \\
\hline 11. CEO tenure squared & 0.99 & 2.69 & -.06 & -.05 & -.13 & .02 & -.10 & -.05 & .36 & -.06 & -.15 & .75 & 1.00 & & & \\
\hline 12. CEO duality & 0.66 & 0.48 & -.09 & .04 & -.02 & .04 & -.06 & -.04 & .28 & .16 & .13 & .30 & .09 & 1.00 & & \\
\hline 13. Board incentives & 0.7 & 0.28 & -.06 & -.13 & .23 & -.02 & -.00 & .09 & -.12 & .02 & -.00 & -.03 & -.08 & -.04 & 1.00 & \\
\hline 14. Board attendance & -0.1 & 0.34 & -.03 & -.13 & .02 & -.01 & .04 & -.03 & .01 & .04 & .01 & -.03 & -.03 & -.02 & .01 & 1.00 \\
\hline
\end{tabular}

Note: $N=2,864$. Correlation coefficients larger in absolute value than .04 are significant at $p<.05$.

Journal of Management, (June 4, 2014). DOI. This article is @ SAGE Publications and permission has been granted for this version to appear in e-Publications@Marquette. SAGE Publications does not grant permission for this article to be further copied/distributed or hosted elsewhere without the express permission from SAGE Publications. 
In addition, we control for factors likely to influence CEO compensation including the proportion of CEO variable pay, average CEO peer compensation, the gap between CEO pay and that of other officers of the company, firm performance volatility, and annual performance. CEO variable pay is measured by calculating the proportion of noncash contingent pay as a percentage of total compensation to focus on long-term variable pay. We excluded cash bonuses because prior research suggests that this form of contingent pay is less variable over time (Larraza-Kintana, Wiseman, GomezMejia, \& Welbourne, 2007) and may in fact be used to avoid tax penalties that accrue when base salary exceeds one million dollars per annum. Peer pay reflects the pay of peer CEOs in the industry and is included to capture labor market influences on the focal CEO's pay (David, Kochhar, \& Levitas, 1998). Peer pay is calculated as the average total compensation for CEOs in a three-digit NAICS industry code excluding the focal CEO. We also controlled for the difference in pay between the CEO and the next level of executives or what is termed as pay gap. Pay gap is measured as the percentage difference in total compensation between the CEO and the second-highest-paid executive. Performance volatility represents firm risk and as volatility increases CEOs require an additional risk premium to agree to work for a riskier firm (cf. Shavell, 1979). This variable is measured as the 60month moving average of stock price volatility (Bekaert, Harvey, Lundblad, \& Siegel, 2007). Firm performance is measured as firm return on assets and accounts for business cycle effects. Drawing on prior research we control for CEO age as a proxy for experience (Cannella \& Shen, 2001). Firm size is measured as the logarithm of firm sales to control for size effects known to explain a large portion of the variance in CEO pay (Tosi et al., 2000). CEO turnover is a dummy variable that is coded 1 for years there was a change in the position of CEO and 0 otherwise. We also include year dummies to account for time effects.

To limit the effect of extreme outliers, the measures of peer pay, board meetings, pay gap, performance volatility, board incentives, and board attendance are winsorized at the 99 percentile (Haleblian, McNamara, Kolev, \& Dykes, 2012; McNamara, Haleblian, \& Dykes, 2008). We checked the variance inflation factors, and none of them was larger than 4.71, indicating no multicollinearity issues.

Journal of Management, (June 4, 2014). DOI. This article is (C) SAGE Publications and permission has been granted for this version to appear in e-Publications@Marquette. SAGE Publications does not grant permission for this article to be further copied/distributed or hosted elsewhere without the express permission from SAGE Publications. 
NOT THE PUBLISHED VERSION; this is the author's final, peer-reviewed manuscript. The published version may be accessed by following the link in the citation at the bottom of the page.

Finally, with the exception of shareholder returns all independent and control variables were lagged at period $\mathrm{t}-1$.

\section{Estimation Procedures}

The data for our study consists of yearly observations of CEO and firm variables. Thus, it is a panel data model that prevents us from using ordinary least squares regression (e.g., Bliese, 2000; Devers, McNamara, Wiseman, \& Arrfelt, 2008). In addition, our panel consists of multiple cross-sectional units and very few time periods per unit. To properly address the specificities of our data, we utilize the Arellano-Bond generalized method of moments (GMM) estimation method (Arellano \& Bond, 1991; Roodman, 2006). This method provides several advantages. First, Arellano-Bond provides a very robust estimation and is preferred for autoregressive-distributed lag panel data sets with multiple cross-sectional units and few time periods. Second, while inclusion of a lagged value of the dependent variable allows us to control for the impact of prior CEO relative returns on future CEO relative returns, the lagged dependent variable is likely to be correlated with the error term (Greene, 2000). Such a problem is avoided in Arellano-Bond GMM estimation. Third, panel data are often subject to autocorrelation, which is also likely in our sample (using the Wooldridge test we rejected the null hypothesis of no serial autocorrelation). Arellano-Bond estimation effectively addresses such concerns. In addition, Arellano-Bond addresses issues of heteroscedasticity usually present in panel data sets (Arellano, 2003). Finally, the potential endogeneity of the independent variables is accounted for by including their lagged values as instruments.

For our sample we relied on Arellano-Bond estimation utilizing System GMM estimator which increases efficiency and reduces bias (Arellano \& Bover, 1995; Blundell \& Bond, 1998). In addition, System GMM is preferable to Difference GMM estimator because "the persistence of the dependent . . . variable could cause severe weak instrument problems in Difference GMM models" (Uotila, Maula, Keil, \& Zahra, 2009: 226). We utilize GMM with orthogonal deviations because our data panel is unbalanced (Alessandri, Tong, \& Reuer, 2012; Arellano \& Bover, 1995; Roodman, 2006). In addition, we used a twostep estimator with robust standard errors and a two-lag structure of the instruments to deal with autocorrelation and heteroscedasticity

Journal of Management, (June 4, 2014). DOI. This article is (C) SAGE Publications and permission has been granted for this version to appear in e-Publications@Marquette. SAGE Publications does not grant permission for this article to be further copied/distributed or hosted elsewhere without the express permission from SAGE Publications. 
(e.g., Alessandri et al., 2012; Dokko \& Gaba, 2012). Results showed that the two-lag structure successfully eliminates autocorrelation problems. We tested the possibility of endogeneity of some of our variables by including instruments, which represent lagged values of those variables. Including lagged values of CEO relative returns, pay gap, tenure, and duality provided consistent results with the ones reported in the article, which increases the credibility and confidence in the approach we applied. As a robustness test, we also ran our analyses with orthogonal deviations and without orthogonal deviations, with and without robust standard errors, with a two-step and singlestep estimator, with two-, three-, and four-lag structure. Overall, results are consistent with those reported in the current article. ${ }^{3}$

In Tables 2 and 4 we report the Hansen statistic and the tests for autocorrelation. Results indicate that instruments are valid and not correlated with the error terms (Lim \& McCann, 2013; Vandaie \& Zaheer, 2014) and there is no evidence of autocorrelation.

Table 4

Arellano-Bond Dynamic Panel Regression Predicting CEO Relative Returns

\begin{tabular}{|c|c|c|c|c|c|c|c|c|c|c|c|c|}
\hline \multirow[b]{2}{*}{ Variable } & \multicolumn{2}{|c|}{ Model 1} & \multicolumn{2}{|c|}{ Model 2} & \multicolumn{2}{|c|}{ Model 3} & \multicolumn{2}{|c|}{ Model 4} & \multicolumn{2}{|c|}{ Model 5} & \multicolumn{2}{|c|}{ Model 6} \\
\hline & Coeff. & $S E$ & Coeff. & $S E$ & Coeff. & $S E$ & Coeff. & $S E$ & Coeff. & $S E$ & Coeff. & $S E$ \\
\hline Constant & $0.79^{* * *}$ & 0.15 & $0.6^{* * *}$ & 0.15 & $0.62^{* * *}$ & 0.15 & $0.63^{* * *}$ & 0.15 & $0.83^{* * *}$ & 0.15 & $0.73^{* * * *}$ & 0.15 \\
\hline Lagged CEO relative returns & $-0.06^{+}$ & 0.03 & $-0.06^{+}$ & 0.03 & $-0.06^{+}$ & 0.03 & $-0.06^{\dagger}$ & 0.03 & $-0.06^{+}$ & 0.03 & $-0.06^{+}$ & 0.03 \\
\hline Board size & 0.003 & 0.01 & -0.0002 & 0.01 & -0.001 & 0.01 & 0.003 & 0.01 & -0.00 & 0.01 & -0.005 & 0.01 \\
\hline CEO variable pay & -0.03 & 0.05 & $-0.09^{+}$ & 0.05 & -0.08 & 0.05 & -0.08 & 0.05 & -0.05 & 0.05 & -0.06 & 0.05 \\
\hline Peer pay & 0.000 & 0.00 & 0.000 & 0.000 & 0.000 & 0.000 & 0.000 & 0.000 & 0.000 & 0.000 & 0.000 & 0.00 \\
\hline Board meetings & 0.01 & 0.01 & 0.003 & 0.01 & 0.003 & 0.01 & 0.01 & 0.01 & 0.01 & 0.01 & 0.003 & 0.01 \\
\hline Institutional ownership & $-0.07^{*}$ & 0.04 & $-0.08^{*}$ & 0.04 & $-0.07^{*}$ & 0.04 & $-0.07^{*}$ & 0.04 & $-0.06^{+}$ & 0.04 & $-0.07^{\dagger}$ & 0.04 \\
\hline CEO age & $-0.01^{* * *}$ & 0.002 & $-0.01^{* * *}$ & 0.002 & $-0.01^{* * *}$ & 0.002 & $-0.01^{* * *}$ & 0.002 & $-0.01^{* * *}$ & 0.002 & $-0.01 * * *$ & 0.002 \\
\hline Pay gap & 0.001 & 0.02 & 0.004 & 0.02 & 0.01 & 0.02 & 0.01 & 0.02 & 0.01 & 0.02 & 0.02 & 0.02 \\
\hline Board independence & $0.23^{* *}$ & 0.09 & $0.18^{*}$ & 0.09 & $0.2^{*}$ & 0.09 & $0.26^{* *}$ & 0.08 & $0.22^{* *}$ & 0.08 & $0.20^{*}$ & 0.08 \\
\hline Year dummies & \multicolumn{2}{|c|}{ Included } & Included & & Included & & \multicolumn{2}{|l|}{ Included } & \multicolumn{2}{|l|}{ Included } & \multicolumn{2}{|l|}{ Included } \\
\hline CEO tenure & & & $-0.01^{* * *}$ & 0.002 & $-0.02^{* * *}$ & 0.003 & & & & & $-0.02^{* * *}$ & 0.003 \\
\hline CEO tenure squared & & & & & $0.03^{* * * *}$ & 0.01 & & & & & $0.02 * * *$ & 0.01 \\
\hline CEO duality & & & & & & & $-0.08^{*}$ & 0.03 & & & -0.03 & 0.03 \\
\hline Board incentives & & & & & & & & & $-0.16^{* * *}$ & 0.04 & $-0.15 * *$ & 0.04 \\
\hline Board attendance & & & & & & & & & $-0.07+$ & 0.04 & $-0.08^{*}$ & 0.04 \\
\hline$N$ & \multicolumn{2}{|c|}{2,864} & \multicolumn{2}{|c|}{2,864} & \multicolumn{2}{|c|}{2,864} & \multicolumn{2}{|c|}{2,864} & \multicolumn{2}{|c|}{2,864} & \multicolumn{2}{|c|}{2,864} \\
\hline Wald $\chi^{2}$ & \multirow{2}{*}{\multicolumn{2}{|c|}{$78 * * *$}} & \multicolumn{2}{|c|}{$107^{* * * *}$} & \multicolumn{2}{|c|}{$121^{* * * *}$} & \multicolumn{2}{|c|}{$86^{* * *}$} & \multicolumn{2}{|c|}{$95^{* * *}$} & \multicolumn{2}{|c|}{$134^{* * * *}$} \\
\hline$\Delta$ Wald $\chi^{2}$ & & & \multirow{2}{*}{\multicolumn{2}{|c|}{$29 * * *$}} & \multirow{2}{*}{\multicolumn{2}{|c|}{$43^{* * *}$}} & \multicolumn{2}{|c|}{$8^{* *}$} & \multirow{2}{*}{\multicolumn{2}{|c|}{$17^{* * * *}$}} & \multicolumn{2}{|c|}{$56^{* * *}$} \\
\hline$p$ values & & & & & & & & & & & & \\
\hline AR(1) test & \multicolumn{2}{|c|}{.00} & \multicolumn{2}{|l|}{.00} & .00 & & .00 & & .00 & & .00 & \\
\hline $\operatorname{AR}(2)$ test & .17 & & .17 & & .17 & & .17 & & .16 & & .17 & \\
\hline Hansen test & .6 & & .65 & & .66 & & .64 & & .63 & & .67 & \\
\hline
\end{tabular}

Note: $S E=$ robust standard errors. $\Delta$ Wald $\chi^{2}$ values are based on differences with the controls-only model. The last three rows provide specification tests for the Arellano-Bond generalize method of moments (GMM) system estimator. For all models the $z$ statistic for AR(2) tests ranges from 1.36 to 1.39 and the $p$ values exceed .1, which indicate no serial autocorrelation. The Hansen statistic for all models ranges from 4.09 to 4.33 and the $p$ values exceed .1 , which indicate that instruments are exogenous and valid (Lim \& McCann, 2013; Vandaie \& Zaheer, 2014). $\frac{1}{t} p<.1$.

$\because p<.05$.

$* * p<0.01 .001$.

Journal of Management, (June 4, 2014). DOI. This article is (C SAGE Publications and permission has been granted for this version to appear in e-Publications@Marquette. SAGE Publications does not grant permission for this article to be further copied/distributed or hosted elsewhere without the express permission from SAGE Publications. 
NOT THE PUBLISHED VERSION; this is the author's final, peer-reviewed manuscript. The published version may be accessed by following the link in the citation at the bottom of the page.

\section{Results}

Before presenting our results for Hypotheses 2 to 4, we would like to stress that positive (negative) correlation between our independent variables and our dependent variable indicates that CEOs are able to capture larger (smaller) share of firm residuals than shareholders. Tables 1 and 3 provide descriptive statistics and correlations for the variables in our model.

Table 2 provides results from regressing CEO returns on shareholder returns and other factors and serves to test Hypothesis 1. The relationship between shareholder returns and CEO returns has a parameter value of $1.295(p<.001)$, indicating that for every unit increase in shareholder returns, CEO returns increase an additional $29.5 \%$ more than shareholder returns. Thus, Hypothesis 1 is strongly supported.

Meanwhile, firm size has a positive influence on the size of CEO returns, while firm performance has a negative influence. This latter finding provides some support that CEOs are able to partially insulate their income from shifts in firm performance.

Table 4 provides the results for our Hypotheses 2 to 4 . Model 1 of Table 4 includes only the control variables. The majority of our control variables are not significant, with several exceptions. The negative association between CEO age and CEO returns indicates that younger (and probably less wealthy) CEOs are more likely to extract higher returns from the firm than shareholders. Institutional ownership is significant suggesting that the presence of large institutional investors constrains CEOs in capturing larger returns. The positive association between board independence and CEO relative returns provides support for the sociopolitical view that board member economic independence masks social ties to the CEO that can undermine board efforts to control CEO opportunism (Westphal \& Stern, 2006).

Models 2 to 6 of Table 4 add our primary variables of interest. Hypothesis 2 predicts that CEO relative returns will decrease as CEO tenure increases, but that this decrease in relative returns will occur at a decreasing rate. In support of Hypothesis 2, we find that CEO tenure

Journal of Management, (June 4, 2014). DOI. This article is @ SAGE Publications and permission has been granted for this version to appear in e-Publications@Marquette. SAGE Publications does not grant permission for this article to be further copied/distributed or hosted elsewhere without the express permission from SAGE Publications. 
has a negative main effect $(p<.001)$, while tenure squared has a positive association $(p<.001)$. The convex relationship is presented in Figure 1 . Hypothesis 3 predicts a positive association between CEO duality and CEO relative returns. The coefficient in Model 4 is negatively correlated $(p<.05)$ with CEO relative returns indicating that when a CEO is also the chairperson of the board, she or he realizes less excessive returns. Thus, Hypothesis 3 is not supported. Hypothesis 4 predicts that board diligence should constrain CEO relative returns. Results support this prediction: In particular, we find a significant negative association $(p<.01)$ between board incentives and CEO relative returns and a significant negative correlation ( $p$ $<.05$ ) between director attendance and CEO relative returns. Thus, Hypothesis 4 is supported.

Figure 1. Relationship Between CEO Tenure and CEO Relative Returns

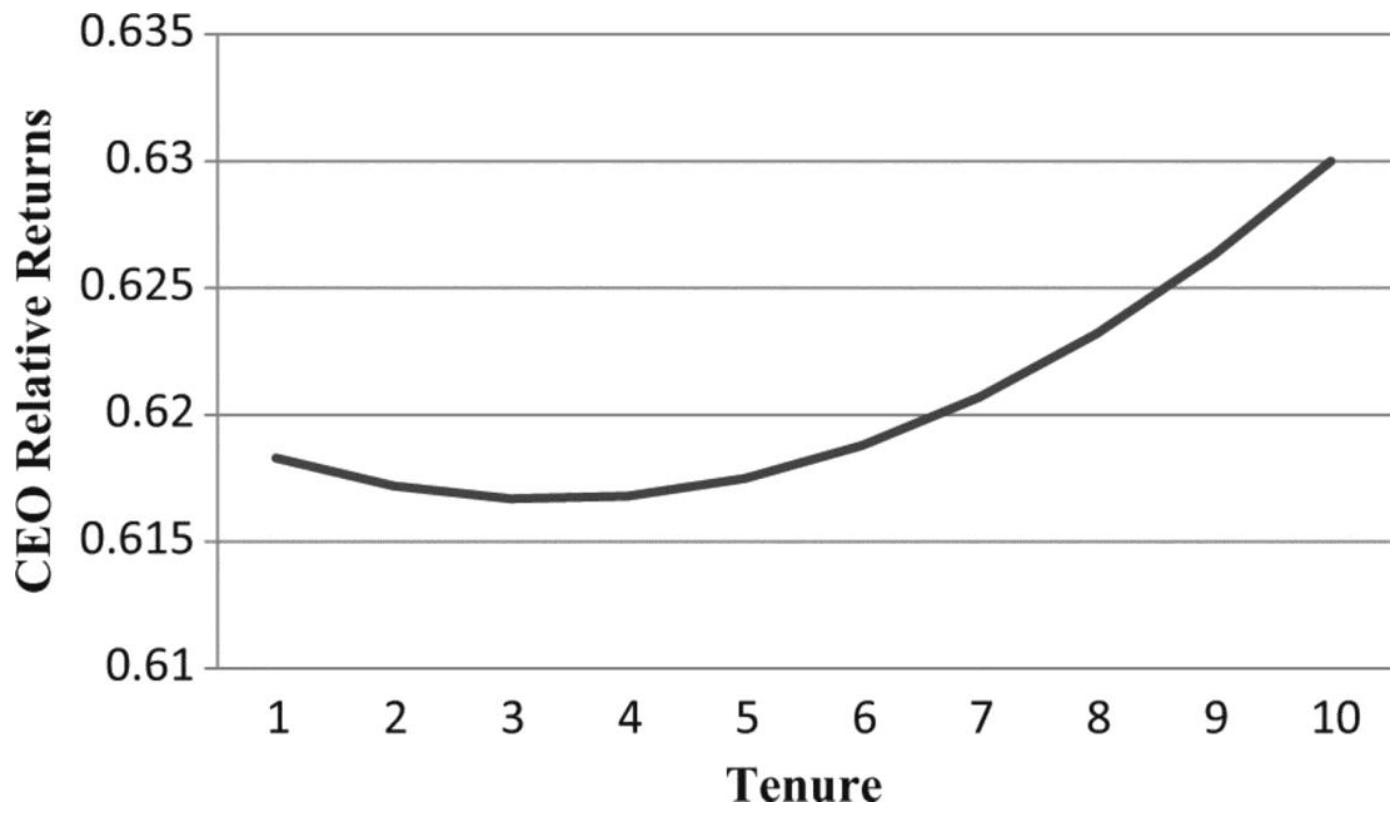

\section{Discussion}

In this study we have argued and empirically demonstrated that when enabling conditions exist, CEOs are able to take advantage of them and capture a larger share of firm residuals than shareholders. That is, norms of distributive justice that place shareholders front and center in the allocation of firm residuals are more likely to be violated when there is evidence of weak procedural justice in corporate

Journal of Management, (June 4, 2014). DOI. This article is @ SAGE Publications and permission has been granted for this version to appear in e-Publications@Marquette. SAGE Publications does not grant permission for this article to be further copied/distributed or hosted elsewhere without the express permission from SAGE Publications. 
governance. In particular, CEOs capture higher returns when they have greater power and those returns are less susceptible to firm performance fluctuations earlier in their tenure when CEOs' value to the firm is likely highest. Conversely, they are able to reduce any loss of power due to obsolescence of their human capital by developing and strengthening social ties to board members. Stated in a different way, under these enabling conditions CEOs are better able to extract personal gain by decoupling their equity-based returns from those of shareholders. Thus, despite the push for tying CEO pay to firm performance through equity forms of compensation, CEOs have captured an increasing share of firm residuals relative to shareholders while simultaneously insulating their firm-specific wealth from fluctuations in firm value. This finding corresponds to the view that CEOs hold managerial power over boards that set their compensation and use that power to increase the portion of firm residuals they extract from the firm (Bebchuk \& Fried, 2004). That CEOs realize greater returns than shareholders, who presumably have primacy in claiming rights to residuals (Hansmann \& Kraakman, 2001), supports charges that CEO compensation violates normative views of distributive justice (Bogle, 2008; Walsh, 2008).

With regard to the role of the board of directors, we encounter a much more nuanced picture. Though we offered no prediction concerning full board independence, we find that it exhibits a positive association with CEO relative returns. In other words, the more outsiders on the board the more likely CEOs will negotiate for more income at lower risk. This finding corresponds to arguments that a focus on the degree of economic independence between board members and the firm masks social dynamics on the board that are often invisible to outside observers. In particular, research in the sociopolitical perspective of corporate governance highlights how top executives seek to manage the impressions of external constituents about governance structures, policies, and procedures (Westphal \& Zajac, 1994, 1998; Zajac \& Westphal, 1995). An effective way for selfserving CEOs to enhance the legitimacy of high compensation packages with limited risk is to demonstrate conformity to the prevailing ideologies or institutional forces by symbolically appointing more outside directors to the full board who share strong social ties with them. External constituents and the media, observing formally independent boards with a high level of structural legitimacy, may 
erroneously assume that such a board will also have higher procedural legitimacy to effectively control managerial self-interest (Suchman, 1995). Essentially, a greater proportion of outside directors in the full board might simply represent a smoke screen or a "pretend" application of the theoretical agency logic of evaluator-evaluated independence when in fact there may well be collusion or a communality of interest between the board and CEO, such that CEOs are able to extract greater share of firm residuals.

\section{Justice Implications}

From a normative perspective, the presence of what we are calling CEO relative returns suggests that the allocation of firm residuals to CEOs is undeserved and thus represents a violation of distributive justice as well as an agency cost. Given that CEOs enjoy a larger share of firm residuals than do shareholders, and this share corresponds to strong bargaining power of the CEO matched with weak monitoring by the board, this would seem evidence of CEO rentseeking behavior and a "misappropriation" of shareholder wealth by the CEO. In other words, greater returns by CEOs vis-à-vis shareholders may be normatively construed as a manifestation of agent opportunism resulting in inequitable distributive justice, assuming that investors are the primary claimants of firm residuals. While there is no precise a priori point at which the allocation of firm residuals between CEO and shareholders is determined as optimal, it is clear that a growing segment of society, including shareholders using only anecdotal evidence, is questioning the justification of this allocation from a normative perspective. This study provides empirical evidence that CEOs are winning at the expense of shareholders. Still, defenders of compensation practices might argue that there is a positive motivational value when CEOs capture higher firm residuals since the size of the pie will be larger for all concerned (the proverbial "win-win" situation). For instance, the excess returns may offer an inducement to CEOs to increase effort, make better investment decisions, improve cost controls and the like which should improve subsequent firm performance. In a supplementary analysis, we did not find support for this view. More specifically, for the period 2001 to 2008 we estimated how CEO relative returns relate to future firm performance. The association was negative but not statistically

Journal of Management, (June 4, 2014). DOI. This article is @ SAGE Publications and permission has been granted for this version to appear in e-Publications@Marquette. SAGE Publications does not grant permission for this article to be further copied/distributed or hosted elsewhere without the express permission from SAGE Publications. 
significant suggesting that CEO relative returns do not coincide with increased firm performance; this finding supports our arguments that CEO relative returns represent a violation of distributive justice where CEOs capture a larger share of firm residuals compared to shareholders.

We argued and found strong support that when directors are diligent (e.g., attend regularly board meetings and have strong incentives to monitor CEOs due to their own incentive pay arrangements), they are more likely to exercise their control function and thus constrain CEO relative returns. In other words, in addition to regular board attendance an important condition to secure directors' effective oversight is to make them partial owners in the firm and tie part of their compensation to the fortunes of that firm. This suggests a hierarchy of incentive alignment emerges, such that incentive alignment between board members and shareholders results in greater alignment between CEOs and shareholders.

We also found results that are opposite to our theorizing. In particular, rather than increasing CEO relative returns, duality decreased the amount of firm residuals captured by CEOs. We believe that the sociopolitical perspective could explain these findings. A savvy CEO, knowing the prevailing social norms and expectations for reduced CEO power, could voluntarily give the appearance of self-sacrificing power and influence to the board by avoiding the position of CEOchair. While the separation of the CEO and chairman positions helps gain external legitimacy, a CEO could still leverage her or his social ties and friendship connections with board members to gain larger relative returns (e.g., Westphal \& Stern, 2006). In other words, abuse of power would be too obvious for a CEO-chair to receive higher returns, and hence one way to prevent that inference is to limit those returns. It might also be the case that boards may appoint CEO-chairs when the board believes that the CEO will not do things that compromise the perceived ethicality of the board (for instance, by securing egregious compensation). This represents an interesting area for future research.

Finally, our study only focuses on the conditions that allow CEOs to gain returns from equity-based contingent compensation. This allowed us to avoid contaminating our measure of CEO returns with

Journal of Management, (June 4, 2014). DOI. This article is @ SAGE Publications and permission has been granted for this version to appear in e-Publications@Marquette. SAGE Publications does not grant permission for this article to be further copied/distributed or hosted elsewhere without the express permission from SAGE Publications. 
compensation that is not shared by investors (such as base salary, other compensation, severance pay, and nonpecuniary forms of compensation). These forms have been argued to provide the risk premium that CEOs may demand as their reservation wage to accept the increased risk bearing that incentive alignment creates. Future research should consider whether this argument is justified. In addition, we were unable to capture the behavior of shareholders directly leaving this as a possible avenue for future research.

Future research may also consider the role of board committees separately from the full board, such as the compensation committee. We believe that compensation committees may be in a better position to constrain CEO opportunism. In particular, because functional board committees are (a) more subject to direct regulatory institutional pressures (Scott, 2008), more subject to closer scrutiny by outside agencies, and bound by strong professional norms and codes of ethics (such as accredited compensation experts who are members of the Society for Human Resource Management) and (b) expected to perform much more focused, explicit, and unambiguous tasks, generally requiring highly specialized skills; securing social as well as economic independence of those committees could provide stronger protection of shareholder interests.

\section{Conclusion}

In this study we present a framework that offers new insight into CEO compensation and returns and which provides an innovative approach to represent CEO returns as a portion of overall firm residuals. More specifically, we use shareholder returns as an appropriate referent for gauging whether CEO returns satisfy one normative view of distributive justice. We find that CEOs capture a larger share of firm residuals, which appears to be facilitated by leverage over the board of directors and factors suggesting that violations of normative views of distributive justice can be traced to violations of rules for procedural justice. Thus, the resulting bargaining between CEOs and boards over CEO pay raises questions about both distributive and procedural justice issues in negotiating CEO pay.

As a final point, our theoretical arguments and findings are not meant to imply that the core predictions of agency theory are not

Journal of Management, (June 4, 2014). DOI. This article is (C) SAGE Publications and permission has been granted for this version to appear in e-Publications@Marquette. SAGE Publications does not grant permission for this article to be further copied/distributed or hosted elsewhere without the express permission from SAGE Publications. 
supported. The reader should be reminded that agency theory has been criticized in the past for painting a bleak picture of human nature where selfishness and opportunism, much like the biblical original sin, are taken as given (Bruce, Buck, \& Main, 2005; Davis, Schoorman, \& Donaldson, 1997). ${ }^{4}$ In this study we take a slightly different angle on executive compensation and contend that to better understand it we need to consider the complex interactions and objectives of principals and agents. While principals strive to better align agent interests with their own by attempting to align incentives of CEOs to those of investors, CEOs look for additional compensation to accept such bargains, while also insulating themselves from the risks associated with incentive alignment contracts. Our point is that in bargaining over the allocation of residuals in pursuit of strong pay-performance sensitivity various facilitating or constraining conditions tilt the balance of power between principals and agents to capture larger share of firm residuals, and result in violations of normative views of distributive justice. That is, we need to look beyond pay-performance sensitivity to the allocation of residuals and the procedures used in making that allocation.

\section{Acknowledgments}

We would like to thank Donald Conlon, senior associate editor Patrick Wright, and two anonymous reviewers for their insightful comments and suggestions for improving this article.

\section{Appendix}

\section{Detailed Calculation of CEO Relative Returns}

Drawing on Nyberg and colleagues (2010), we calculated both CEO returns and shareholder returns as ratios. For CEO returns, the numerator equals the sum of cash bonuses, long-term incentive payouts, the value realized from the sale of company stock, and changes in the value of all equity-based components held until the end of the fiscal year (e.g., stock options, restricted stock, and ownership). This approach allows us to include the appreciation in value of all shares not sold during the entire period, the change in intrinsic value of all exercisable and nonexercisable options held at the beginning of the period, the value realized from any equity ownership sold during

Journal of Management, (June 4, 2014). DOI. This article is @ SAGE Publications and permission has been granted for this version to appear in e-Publications@Marquette. SAGE Publications does not grant permission for this article to be further copied/distributed or hosted elsewhere without the express permission from SAGE Publications. 
the period, and the value realized from exercising options and selling the resulting stock during the period. The denominator of CEO returns includes CEO wealth at the beginning of the year (e.g., stock, restricted stock, vested stock, and stock options).

We excluded salary and "other annual" compensation because they are not related to performance, generally reflect the reservation wages paid to CEOs, and are not available to shareholders. Thus, our measure of CEO returns provides a more conservative test of our predictions regarding CEO relative returns. In supplemental analyses, we conducted two robustness tests where we included (a) all nonvariable forms of CEO pay and (b) only variable forms of CEO pay in our measure of CEO returns, but we found no change in our findings.

We calculated CEO returns as CEO income from variable pay during the year divided by CEO firm-specific wealth at the beginning of the year,

$C E O$ return $_{t}=C E O$ variable pay income $e_{t}$ CEO beginning value variable pay wealt $h_{t o}$

where CEO variable pay income $t=$ bonus $_{t}+\mathrm{LTIP}_{t}+$ change in value of unexercised unexercisable and exercisable options $s_{t}+$ change in value of restricted and vested stock $_{t}+$ change in the value of CEO equity ${ }_{t}+$ value realized from exercised optionst.

CEO beginning value variable pay wealth to $=$ beginning value of

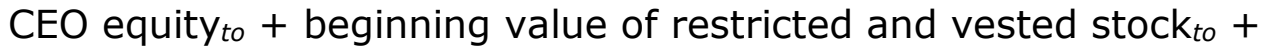
beginning value of unexercised unexercisable and exercisable optionsto.

Shareholder returns are calculated in a similar fashion to CEO returns by creating a ratio of the change in share price over the period plus dividends paid during the period, and then divided by the share price at the beginning of the fiscal year (Yermack, 2006).

CEO returns and shareholder returns were then transformed through an inverse hyperbolic sine function (HIS):

Journal of Management, (June 4, 2014). DOI. This article is C SAGE Publications and permission has been granted for this version to appear in e-Publications@Marquette. SAGE Publications does not grant permission for this article to be further copied/distributed or hosted elsewhere without the express permission from SAGE Publications. 
NOT THE PUBLISHED VERSION; this is the author's final, peer-reviewed manuscript. The published version may be accessed by following the link in the citation at the bottom of the page.

$$
\sinh -1(x)=\log \left(x+\left(x^{2}+1\right)^{1 / 2}\right)
$$

We employed the HIS transformation of our returns measures to reduce the effect of extreme outliers on our model, and to overcome issues related to negative values (Burbidge, Magee, \& Robb, 1988; Nyberg et al., 2010).

\section{Notes}

1. Following the suggestions of an anonymous reviewer, we conducted a supplementary test of our hypotheses. In particular, we used CEO returns as our DV and included shareholder returns as a control variable plus the rest of the control and independent variables. Results from this approach are consistent with those we report in this article and are available from the authors upon request.

2. Recently, Gove and Junkunc (2013) published a study that examines the problems with the duality measure. They point out that prior tests involving duality have produced inconsistent results leading to a debate over its meaning. As they suggest, the problem with this measure rests on an assumption of temporal consistency, which they show lacks empirical validity. Following their recommendations, we conducted a robustness check with an alternative measurement of duality. In particular, we identified instances when duality reflected a temporary event that would not reflect a lasting change in the CEO's bargaining power relative to the board. For example, duality is unlikely to give the CEO lasting bargaining power over the board, if it is created only to assist in the transition of a CEO to the director position while a successor to the CEO is hired. Thus, in instances where duality lasted no more than two periods, we set those observations to zero indicating no duality. This adjustment to the duality measure produced similar results.

3. To provide additional robustness checks and comparability with estimation techniques in prior studies, we also ran our analyses via generalized least squared estimators with autocorrelation controls (Sanders \& Hambrick, 2007), generalized estimating equations (e.g., Sanders \& Hambrick, 2007), and hierarchical linear modeling. Results across all these estimation techniques were the same and are available from the authors.

4. See Gomez-Mejia, Wiseman, and Johnson-Dykes (2005) for a contrasting view.

Journal of Management, (June 4, 2014). DOI. This article is @ SAGE Publications and permission has been granted for this version to appear in e-Publications@Marquette. SAGE Publications does not grant permission for this article to be further copied/distributed or hosted elsewhere without the express permission from SAGE Publications. 
NOT THE PUBLISHED VERSION; this is the author's final, peer-reviewed manuscript. The published version may be accessed by following the link in the citation at the bottom of the page.

\section{References}

Alessandri T. M., Tong T. W., Reuer J. J. 2012. Firm heterogeneity in growth option value: The role of managerial incentives. Strategic Management Journal, 33: 1557-1566.

Arellano M. 2003. Panel data econometrics. Oxford, UK: Oxford University Press.

Arellano M., Bond S. R. 1991. Some tests of specification for panel data: Monte Carlo evidence and an application to employment equations. Review of Economic Studies, 58: 277-297.

Arellano M., Bover O. 1995. Another look at the instrumental variable estimation of error-components models. Journal of Econometrics, 68: 29-51.

Bebchuk L., Fried J. 2004. Pay without performance: The unfulfilled promise of executive compensation. Cambridge, MA: Harvard University Press.

Bebchuk L., Grinstein Y. 2005. The growth of executive pay. Discussion paper no. 510, Harvard Law School, John M. Olin Center for Law, Economics and Business, Cambridge, MA.

Bekaert G., Harvey C. R., Lundblad C., Siegel S. 2007. Global growth opportunities and market integration. Journal of Finance, 62: 1081 1137.

Berle A. A., Means G. C. 1932. The modern corporation and private property. New York: Commerce Clearing House.

Bhojraj S., Sengupta P. 2003. Effect of corporate governance on bond ratings and yields: The role of institutional investors and outside directors. Journal of Business, 76: 455-475.

Bliese P. D. 2000. Within-group agreement, non-independence, and reliability: Implications for data aggregation and analyses. In Klein K. J., Kozlowski S. W. J. (Eds.), Multilevel theory, research, and methods in organization: 349-381. San Francisco: Jossey-Bass.

Blundell R., Bond S. 1998. Initial conditions and moment restrictions in dynamic panel data models. Journal of Econometrics, 87: 115-143.

Journal of Management, (June 4, 2014). DOI. This article is C SAGE Publications and permission has been granted for this version to appear in e-Publications@Marquette. SAGE Publications does not grant permission for this article to be further copied/distributed or hosted elsewhere without the express permission from SAGE Publications. 
NOT THE PUBLISHED VERSION; this is the author's final, peer-reviewed manuscript. The published version may be accessed by following the link in the citation at the bottom of the page.

Bogle J. C. 2008. Reflections on CEO compensation. Academy of Management Perspectives, 22: 21-25.

Boyd B. K. 1995. CEO Duality and firm performance: A contingency model. Strategic Management Journal, 16: 301-312.

Bruce A., Buck T., Main B. 2005. Top executive remuneration: A view from Europe. Journal of Management Studies, 42: 1493-1506.

Burbidge J. B., Magee L., Robb A. L. 1988. Alternative transformations to handle extreme values of the dependent variable. Journal of the American Statistical Association, 83: 123-127.

Cannella A. A., Lubatkin M. 1993. Succession as a sociopolitical process: Internal impediments to outsider selection. Academy of Management Journal, 36: 763-793.

Cannella A. A., Shen W. 2001. So close and yet so far: Promotion versus exit for CEO heir apparent. Academy of Management Journal, 44: 252-270.

Coffee J.C. 1988. Shareholder versus managers: The strain in the corporate web. In Coffee J. C., Lowenstein L., Rose-Acherman S. (Eds.), Knights, raiders, targets: 40-62. New York: Oxford University Press.

Colquitt J. A., Conlon D. E., Wesson M. J., Porter C. O. L. H., Ng K. Y. 2001. Justice at the millennium: A meta-analytic review of 25 years of organizational justice research. Journal of Applied Psychology, 86:

Combs J. G., Skill M. S. 2003. Managerialist and human capital explanations for key executive pay premiums: A contingency perspective. Academy of Management Journal, 46: 63-73.

Core J. E., Guay W. R. 2010. Is CEO pay too high and are incentives too low? A wealth-based contracting framework. Academy of Management Perspectives, 24: 5-19.

Core J., Holthausen R., Larcker D. 1999. Corporate governance, chief executive officer compensation, and firm performance. Journal of Financial Economics, 51: 371-406.

Dalton D. R., Daily C. M., Certo S. T., Roengpitya R. 2003. Meta-analyses of financial performance and equity: Fusion or confusion? Academy of Management Journal, 46: 13-26.

Journal of Management, (June 4, 2014). DOI. This article is @ SAGE Publications and permission has been granted for this version to appear in e-Publications@Marquette. SAGE Publications does not grant permission for this article to be further copied/distributed or hosted elsewhere without the express permission from SAGE Publications. 
NOT THE PUBLISHED VERSION; this is the author's final, peer-reviewed manuscript. The published version may be accessed by following the link in the citation at the bottom of the page.

Dalton D. R., Daily C. M., Ellstrand A. E., Johnson J. L. 1998. Meta-analytic reviews of board composition, leadership, and financial performance. Strategic Management Journal, 19: 269-290.

Dalton D. R., Daily C. M., Johnson J. L., Ellstrand A. E. 1999. Number of directors and financial performance: A meta-analysis. Academy of Management Journal, 42: 674-686.

David P., Kochhar R., Levitas E. 1998. The effect of institutional investors on the level and mix of CEO compensation. Academy of Management Journal, 41: 200-208.

Davis J. H., Schoorman F. D., Donaldson L. 1997. Toward a stewardship theory of management. Academy of Management Review, 22: 20-47.

Deutsch C. H. 2008. Executive pay: A special report; a brighter spotlight, yet the pay rises. New York Times, April 6.

Devers C. E., Cannella A. A. Jr.., Reilly G. P., Yoder M. E. 2007. Executive compensation: A multidisciplinary review of recent developments. Journal of Management, 33: 1016-1072.

Devers C. E., McNamara G., Wiseman R. M., Arrfelt M. 2008. Moving closer to the action: Examining compensation design effects on firm risk. Organization Science, 19: 548-566.

Dokko G., Gaba V. 2012. Venturing into new territory: Career experiences of corporate venture capital managers and practice variation. Academy of Management Journal, 55: 563-583.

Eccles R. 1985. Transfer pricing as a problem of agency. In Pratt J., Zeckhauser R. (Eds.), Principal and agents: The structure of business: 151-186. Boston: Harvard Business School Press.

Edwards J. R. 1996. Regression analysis as an alternative to difference scores. Journal of Management, 20: 683-689.

Eisenhardt K. 1989. Agency theory: An assessment and review. Academy of Management Review, 14: 57-74.

Fama E. F., Jensen M. C. 1983. Agency problems and residual claims. Journal of Law and Economics, 26: 327-349.

Journal of Management, (June 4, 2014). DOI. This article is (C) SAGE Publications and permission has been granted for this version to appear in e-Publications@Marquette. SAGE Publications does not grant permission for this article to be further copied/distributed or hosted elsewhere without the express permission from SAGE Publications. 
NOT THE PUBLISHED VERSION; this is the author's final, peer-reviewed manuscript. The published version may be accessed by following the link in the citation at the bottom of the page.

Finkelstein S., D'Aveni R. A. 1994. CEO duality as a double-edged sword: How boards of directors balance entrenchment avoidance and unity of command. Academy of Management Journal, 37: 1079-1108.

Finkelstein S., Hambrick D. C. 1989. Chief executive compensation: A study of the intersection of markets and political processes. Strategic Management Journal, 10: 121-134.

Fong E. A., Misangyi V. F., Tosi H. L. 2010. The effect of CEO pay deviations on CEO withdrawal, firm size, and firm profits. Strategic Management Journal, 31: 629-651.

Frydman C., Saks R. E. 2010. Executive compensation: A new view from a long-term perspective, 1936-2005. Review of Financial Studies, 23: 2099-2138.

Gomez-Mejia L. R., Berrone P., Franco-Santos M. 2010. Compensation and organizational performance: Theory, research and practice. Armonk, NY: M.E. Sharpe.

Gomez-Mejia L. R., Wiseman R. M. 1997. Reframing executive compensation: An assessment and outlook. Journal of Management, 23: 291-374.

Gomez-Mejia L. R., Wiseman R. M., Johnson-Dykes B. 2005. Agency problems in diverse contexts: A global perspective. Journal of Management Studies, 42: 1507-1517.

Gove S., Junkunc M. 2013. Dummy constructs? Binomial categorical variables as representations of constructs: CEO duality through time. Organizational Research Methods, 16: 100-126.

Greenberg J. 1990. Organizational justice: Yesterday, today, and tomorrow. Journal of Management, 16: 399-432.

Greene W. H. 2000. Econometric analysis (4th ed.). Upper Saddle River, NJ: Prentice Hall.

Haleblian J., McNamara G., Kolev K., Dykes B. 2012. Exploring firm characteristics that differentiate leaders from followers in industry merger waves: A competitive dynamics approach. Strategic Management Journal, 33: 1037-1052.

Journal of Management, (June 4, 2014). DOI. This article is (C) SAGE Publications and permission has been granted for this version to appear in e-Publications@Marquette. SAGE Publications does not grant permission for this article to be further copied/distributed or hosted elsewhere without the express permission from SAGE Publications. 
NOT THE PUBLISHED VERSION; this is the author's final, peer-reviewed manuscript. The published version may be accessed by following the link in the citation at the bottom of the page.

Hambrick D. C., Cannella A. A. 2004. CEOs who have COOs: Contingency analysis of an unexplored structural form. Strategic Management Journal, 25: 959-979.

Hambrick D. C., Fukutomi G. 1991. The seasons of a CEO's tenure. Academy of Management Review, 16: 719-742.

Hansmann H., Kraakman R. 2001. The end of history for corporate law. Georgetown Law Review, 89: 439-468.

Harris D., Helfat C. 1997. Specificity of CEO human capital and compensation. Strategic Management Journal, 18: 895-920.

Henderson A. D., Miller D., Hambrick D. C. 2006. How quickly do CEOs become obsolete? Industry dynamism, CEO tenure, and company performance. Strategic Management Journal, 27: 447-460.

Hill C. W. L., Phan P. 1991. CEO tenure as a determinant of CEO pay. Academy of Management Journal, 34: 707-717.

Jensen M. C., Meckling W. H. 1976. Theory of the firm: Managerial behavior, agency costs and ownership structure. Journal of Financial Economics, 3: $305-360$.

Kaplan S. N. 2008. Are U.S. CEOs overpaid? Academy of Management Perspectives, 22: 5-34.

Kim P. H., Fragale A. R. 2005. Choosing the path to bargaining power: An empirical comparison of BATNAs and contributions in negotiation. Journal of Applied Psychology, 90: 373-381.

Kirkland R., Burke D. 2006. The real CEO pay problem. Fortune, June 30.

Kroll M., Walters B. A., Wright P. 2008. Board vigilance, director experience, and corporate outcomes. Strategic Management Journal, 29: 363-382.

Larraza-Kintana M., Wiseman R. M., Gomez-Mejia L. R., Welbourne T. M. 2007. Disentangling compensation and employment risks using the behavioral agency model. Strategic Management Journal, 28: 10011019.

Leventhal G. S. 1980. What should be done with equity theory? New approaches to the study of fairness in social relationships. In Gergen

Journal of Management, (June 4, 2014). DOI. This article is (C) SAGE Publications and permission has been granted for this version to appear in e-Publications@Marquette. SAGE Publications does not grant permission for this article to be further copied/distributed or hosted elsewhere without the express permission from SAGE Publications. 
NOT THE PUBLISHED VERSION; this is the author's final, peer-reviewed manuscript. The published version may be accessed by following the link in the citation at the bottom of the page.

K., Greenberg M., Willis R. (Eds.), Social exchange: Advances in theory and research: 27-55. New York: Plenum.

Leventhal G. S., Karuza J., Fry W. R. 1980. Beyond fairness: A theory of allocation preferences. In Mikula G. (Eds.), Justice and social interaction: 167-218. New York: Springer-Verlag.

Lim E. N. K., McCann B. T. 2013. The influence of relative values of outside director stock options on firm strategic risk from a multiagent perspective. Strategic Management Journal, 13: 1568-1590.

Lissak R. I. 1983. Procedural fairness: How employees evaluate procedures. Unpublished doctoral dissertation, University of Illinois.

Loomis C. J. 2009. AIG: The company that came to dinner. Fortune, January 19: $70-78$.

Mace M. L. 1971. Directors: Myth and reality. Cambridge, MA: Harvard University, Graduate School of Business Administration.

Marx K. 1906. Capital: A critique of political economy. New York: Modern Library.

Mathieu J. E., Zajac D. M. 1990. A review and meta-analysis of the antecedents, correlates, and consequences of organizational commitment. Psychological Bulletin, 108: 171-194.

McNamara G., Haleblian J., Dykes B. 2008. The performance implications of participating in an acquisition wave: Early mover advantages, bandwagon effects, and the moderating influence of industry characteristics and acquirer tactics. Academy of Management Journal, 51: 113-130.

Milkovich G. T., Newman J. M., Gerhart B. 2013. Compensation (12th ed.). New York: McGraw-Hill.

Miller D. 1991. Stale in the saddle: CEO tenure and the match between organization and environment. Management Science, 37: 34-52.

Morgenson G. 2013. An unstoppable climb in C.E.O. pay. New York Times, June 29. http://www.nytimes.com/2013/06/30/business/anunstoppable-climb-in-ceo-pay.html?pagewanted=all\&_r=0.

Journal of Management, (June 4, 2014). DOI. This article is (C) SAGE Publications and permission has been granted for this version to appear in e-Publications@Marquette. SAGE Publications does not grant permission for this article to be further copied/distributed or hosted elsewhere without the express permission from SAGE Publications. 
NOT THE PUBLISHED VERSION; this is the author's final, peer-reviewed manuscript. The published version may be accessed by following the link in the citation at the bottom of the page.

Murphy K. J. 1986. Top executives are worth every nickel they get. Harvard Business Review, 64: 125-132.

Murphy K. J. 1999. Executive compensation. In Ashenfelster O., Card D. (Eds.), Handbook of labor economics: 2485-2563. Amsterdam: NorthHolland.

Murphy K. J., Zabojnik J. 2004. A market-based explanation for recent trends. American Economic Review, 94: 192-196.

Nyberg A. J., Fulmer I. S., Gerhart B., Carpenter M. A. 2010. Agency theory revisited: CEO returns and shareholder interest alignment. Academy of Management Journal, 53: 1029-1049.

Ocasio W. 1994. Political dynamics and the circulation of power: CEO succession in U.S. industrial corporations, 1960-1990. Administrative Science Quarterly, 39: 285-312.

O'Connor J. P., Priem R. L., Coombs J. E., Gilley K. M. 2006. Do CEO stock options prevent or promote fraudulent financial reporting? Academy of Management Journal, 49: 483-500.

Pfeffer J. 1981. Management as symbolic action: The creation and maintenance of organizational paradigms. In Cummings L. L., Staw B. M. (Eds.), Research in organizational behavior: 1-52. Greenwich, CT: JAI.

Pinkley R. L., Neale M. A., Bennett R. J. 1994. The impact of alternatives to settlement in dyadic negotiation. Organizational Behavior and Human Decision Processes, 57: 97-116.

Risk Metrics. 2013. http://wrdsweb.wharton.upenn.edu/wrds/tools/variable.cfm?library_id=54\&file_id $=54145$.

Roodman D. 2006. How to do xtabond2: An introduction to "Difference" and "System" GMM in Stata. Working paper no. 103, Center for Global Development, Washington, DC.

Sanders W. G., Hambrick D. C. 2007. Swinging for the fences: The effects of CEO stock options on company risk-taking and performance. Academy of Management Journal, 50: 1055-1078.

Journal of Management, (June 4, 2014). DOI. This article is C SAGE Publications and permission has been granted for this version to appear in e-Publications@Marquette. SAGE Publications does not grant permission for this article to be further copied/distributed or hosted elsewhere without the express permission from SAGE Publications. 
NOT THE PUBLISHED VERSION; this is the author's final, peer-reviewed manuscript. The published version may be accessed by following the link in the citation at the bottom of the page.

Scott W. R. 2008. Institutions and organizations (3rd ed.). Thousand Oaks, CA: Sage.

Shavell S. 1979. Risk sharing and incentives in the principle and agent relationship. Bell Journal of Economics, 10: 55-73.

Smith A. 1937. The wealth of nations. New York: Modern Library.

St. Onge S. 1993. Variables influencing pay-for-performance perception in a merit pay environment. Academy of Management Proceedings, August 1: $121-125$.

Suchman M. 1995. Managing legitimacy: Strategic and institutional approaches. Academy of Management Review, 20: 517-610.

Thibaut J., Walker L. 1975. Procedural justice: A psychological analysis. Hillsdale, NJ: Lawrence Erlbaum.

Tian J., Haleblian J., Rajagopalan N. 2011. The effects of board human and social capital on investor reactions to new CEO selection. Strategic Management Journal, 32: 731-747.

Tosi H. L., Gomez-Mejia L. R., Loughry M. L., Werner S., Banning K., Katz J., Harris R., Silva P. 1999. Managerial discretion, compensation strategy, and firm performance: The case for the ownership structure. In Ferris G. R. (Eds.), Research in personnel and human resources management, vol. 17: 163-208. Stamford, CT: JAI.

Tosi H. L., Werner S., Katz J. P., Gomez-Mejia L. R. 2000. How much does performance matter? A meta-analysis of CEO pay studies. Journal of Management, 26: 301-339.

Tuggle C. S., Sirmon D. G., Reutzel C. R., Bierman L. 2010. Commanding board of director attention: Investigating how organizational performance and CEO duality affect board members' attention to monitoring. Strategic Management Journal, 31: 946-968.

Tyler T. R., Caine A. 1981. The influence of outcomes and procedures on satisfaction with formal leaders. Journal of Personality and Social Psychology, 41: 642-655.

Journal of Management, (June 4, 2014). DOI. This article is (C) SAGE Publications and permission has been granted for this version to appear in e-Publications@Marquette. SAGE Publications does not grant permission for this article to be further copied/distributed or hosted elsewhere without the express permission from SAGE Publications. 
NOT THE PUBLISHED VERSION; this is the author's final, peer-reviewed manuscript. The published version may be accessed by following the link in the citation at the bottom of the page.

Uotila J., Maula M., Keil T., Zahra S. 2009. Exploration, exploitation, and financial performance: Analysis of S\&P 500 corporations. Strategic Management Journal, 30: 221-231.

Vandaie R., Zaheer A. 2014. Surviving bear hugs: Firm capability, large partner alliances, and growth. Strategic Management Journal, 35: 566577.

Wade J. B., O'Reilly C. A., Pollock T. G. 2006. Overpaid CEOs and underpaid managers: Fairness and executive compensation. Organization Science, 17: 109-122.

Walsh J. P. 2008. CEO compensation and the responsibilities of the business scholar to society. Academy of Management Perspectives, 22: 26-33.

Westphal J. D. 1998. Board games: How CEOs adapt to increases in structural board independence from management. Administrative Science Quarterly, 43: 511-537.

Westphal J. D., Graebner M. E. 2010. A matter of appearances: How corporate leaders manage the impressions of financial analysts about the conduct of their boards. Academy of Management Journal, 53: 1544.

Westphal J. D., Stern I. 2006. The other pathway to the boardroom: How interpersonal influence behavior can substitute for elite credentials and demographic majority status in gaining access to board appointments. Administrative Science Quarterly, 51: 169-204.

Westphal J. D., Zajac E. J. 1994. Substance and symbolism in CEOs' longterm incentive plans. Administrative Science Quarterly, 39: 367-390.

Westphal J. D., Zajac E. J. 1995. Who shall govern? CEO/board power, demographic similarity, and new director selection. Administrative Science Quarterly, 40: 60-83.

Westphal J. D., Zajac E. J. 1998. The symbolic management of stockholders: Corporate governance reforms and shareholder reactions. Administrative Science Quarterly, 43: 127-153.

Williamson O. E. 1985. The economic institutions of capitalism: Firms, markets, relational contracting. New York: Free Press.

Journal of Management, (June 4, 2014). DOI. This article is (C) SAGE Publications and permission has been granted for this version to appear in e-Publications@Marquette. SAGE Publications does not grant permission for this article to be further copied/distributed or hosted elsewhere without the express permission from SAGE Publications. 
NOT THE PUBLISHED VERSION; this is the author's final, peer-reviewed manuscript. The published version may be accessed by following the link in the citation at the bottom of the page.

Wirtz R. A. 2006. Goldilocks in the corner office. The Region (Minneapolis Federal Reserve), December: 22-25, 32-35.

Wiseman R. M. 2009. On the use and misuse of ratios in strategic management research. In Ketchen D., Bergh D. (Eds.), Research methods in strategy and management: 75-110. Stamford, CT: Emerald JAI.

Yermack D. 2006. Flights of fancy: Corporate jets, CEO perquisites, and inferior shareholder returns. Journal of Financial Economics, 80: 211242.

Zajac E. J., Westphal J. D. 1995. Accounting for the explanations of CEO compensation: Substance and symbolism. Administrative Science Quarterly, 40: 283-308. 